\title{
Três perspectivas gestuais para uma performance percussiva: técnica, interpretativa e expressiva
}

\author{
Fernando Chaib (DeCA - INET-MD Universidade de Aveiro, Aveiro, Portugal) \\ fernandochaib@gmail.com
}

\begin{abstract}
Resumo: Esse artigo' propõe uma reflexão sobre a atuação do intérprete percussionista em função dos gestos que o mesmo poderá aplicar sobre uma performance musical. Para uma construção performativa, que acreditamos poder auxiliar na transmissão do conteúdo musical de uma obra, selecionamos três ações gestuais: técnica (relativa aos movimentos corporais); interpretativas (relativa aos exercícios intelectuais) e expressivas (integração das ações corporais e intelectuais). As explicações e análises sobre os fenômenos gestuais são ilustradas com obras consagradas do repertório de percussão.
\end{abstract}

Palavras-chave: gesto em percussão; movimento corporal em música; exercício intelectual e performance.

\section{Three gestural perspectives for a percussive performance: technical, interpretative and expressive}

Abstract: This article aims at providing a reflection towards the percussionist gestures during musical performance. In building a performance we propose to assist the transmission of a work's musical content according to three gestural acts: technical (only related to body motion); interpretative (related to intellectual exercises) and expressive (integration between body and intellect actions). The explanations and analyses of the gesture phenomena are illustrated with standard works of the percussion repertoire.

Keywords: gesture in percussion; body movement in music; intellectual exercise and performance.

\section{Introdução}

Nas artes performativas o fenômeno gestual é encarado de diversos modos, sendo encontradas as mais variadas interpretações sobre o mesmo. Em algumas formas de expressão artística como a música, dança, pintura e teatro, os autores e intérpretes geralmente se apropriam de forma plural do conceito de gesto. GODØY (2010) é enfático ao afirmar como são recentes os estudos que relacionam o gesto com o fenômeno sonoro em específico: "We are only in the beginning of more systematic studies of gestural affordances of music sound, and needless to say, there are very many theoretical and methodological challenges here". GODøY (2010, p.122). Mesmo assim, já existem na literatura especializada alguns conceitos a respeito do fenômeno gestual em música, dos quais nos interessa nesse artigo: sound-producing gestures, compartilhado por DAHL et.al
(2010) e JENSENIUS et. al. (2010) - Instrumental gestures (CADOZ e WANDERLEY, 2000) ou sound-accompanying gestures (DELALANDE, 1988). A partir de algumas reflexões sobre esse objeto buscaremos identificar certas relações gestuais passiveis de serem incutidas e redimensionadas para a performance destinada ao repertório escrito para percussão. Ao considerarmos o movimento corporal uma das principais fontes de expressividade para a elaboração da performance do percussionista, acreditamos que a percepção e o desenvolvimento dos gestos realizados permitirá o alargamento das possibilidades de transmissão e compreensão do conteúdo musical presente na obra executada. Isso poderá gerar diferentes níveis de expressão levando o intérprete a ampliar as suas faculdades e horizontes interpretativos. 
Três diferentes pontos de vista sobre o gesto foram aqui analisados. 0 primeiro, ao qual chamaremos Gesto Percussivo (GP), será o responsável pela extração sonora do instrumento, processo imprescindivel para uma performance musical percussiva. 0 segundo, conceitualizado como Gesto Percussivo Interpretativo (GPI), discutirá o exercício e domínio intelectual do percussionista sobre a obra capaz de outorgar-Ihe um caráter performativo único e original. Finalmente, o terceiro conceito de gesto que denominamos Gesto Percussivo Expressivo (GPE) será a simbiose dos dois gestos anteriores, somados a uma concepção de movimento corporal que transcende as questões técnicas de execução instrumental. Para uma melhor compreensão dos conceitos e suas aplicações práticas na performance em percussão tomaremos como casos de estudo algumas obras de referência existentes no repertório destinado aos instrumentos de percussão ${ }^{2}$.

\section{Gesto Percussivo (GP)}

As discussões que buscam encontrar soluções para as barreiras impostas pelos instrumentos de percussão (ou pela partitura) relativamente à interpretação e expressão musical são, de fato, constantes no universo percussivo. Para além dos meios expressivos (articulações, dinâmicas, ligaduras, etc.), as discrepâncias tímbricas e sonoras (ressonância, reverberação, etc.) caracterizamse como fatores complexos na construção performativa do percussionista. Apesar de as pesquisas envolvendo o gesto relacionado a esse assunto serem recentes observamos que a primeira década do século XXI foi "presenteada" com uma série de trabalhos voltados para este sujeito ${ }^{3}$. Mesmo pertencendo a um mesmo campo de investigação esses trabalhos carregam diferentes abordagens relativas ao objeto de pesquisa. Antecipando essa gama de estudos, BAILEY (1963) já procurava discutir certas problemáticas evidentes na performance para percussão ao afirmar que os percussionistas deveriam desenvolver técnicas que projetassem sensações de legato, mesmo sendo impossível produzir essa ideia no real sentido da palavra.

Tomaremos como base das observações o conceito de Sound-producing gestures definido como: "meaning body movements necessary for producing sound" (GODØY, 2010 p.110). Serão esses movimentos somáticos indispensáveis, o ponto de origem dos gestos corporais ligados à performance musical em percussão. Sem esses primeiros movimentos a execução instrumental percussiva realizada por um indivíduo tornar-se-ia impossivel. Através das observações aqui feitas será possivel determinar o GP como o primeiro gesto realizado pelo percussionista para a extração sonora, ou seja o primeiro contato estabelecido entre intérprete e instrumento. A ideia será justamente observar os meios de execução sobre os instrumentos de percussão para dar a esse conceito uma direção à performance musical. Atos como friccionar, raspar, chocalhar, tactear e apalpar, dentre outras ações que serão expostas integrarão o conceito de GP.
Não obstante observaremos como a percussão se serve de adaptações de técnicas de execução de outras famílias de instrumentos para a sua execução. 0 ato de soprar é uma delas. Para a realização do seu som, muitos apitos possuem uma pequena esfera que debate-se dentro da própria caixa de ressonância do apito produzindo o efeito de um tremolo (dizemos que a esfera chocalha dentro do "corpo" do apito). Para que isso ocorra e produza o som para o qual o apito foi concebido, é necessário soprá-lo. 0 ato em si é o de soprar mas a sua consequência, o som obtido através do chocalhar da esfera, caracterizará a ação como um GP.

Carlos Stasi vai mais além em sua obra Canção Simples de Tambor (1990) solicitando ao percussionista "soprar" em direção à caixa (STASI,1990 p.04). Por ser uma obra escrita para percussão e tendo em conta a contextualização da performance, consideraremos todos os atos realizados durante a execução instrumental como ações de interação percussiva. Mesmo tratando-se de um sopro, essa ação exerceu o papel de fonte de interlocução entre o instrumentista e o instrumento, por tanto desempenhou uma função gestual percussiva.

Outro exemplo será a utilização de arcos de instrumentos de cordas sobre idiofones e instrumentos de lâminas. A relação táctil é praticamente a mesma que a utilizada por violinistas, contrabaixistas, etc. É certo que o deslize do arco para obtenção do som é uma característica dos instrumentos de cordas, mas, ao observarmos um número considerável de obras para percussão que se apropriam dessa técnica, somos obrigados a admitirmos que tratase, em música para percussão, de uma ação percussiva.

Através desses e outros exemplos percebemos como o GP nos conduz à variados atos de percutir, mostrando-se um meio de execução instrumental complexo e multifacetado.

\subsection{Possibilidades de GP (lista de gestos percussivos)}

Para visualizarmos os exemplos de contatos que se seguem, elaboramos uma lista de gestos percussivos (Ex.1) contendo excertos musicais (Ex.2 a Ex.10) que servirão de auxílio para uma melhor compreensão dos conceitos discutidos. Para tal elegemos obras que possuem reconhecida relevância artística no repertório percussivo.

Será importante frisar que o texto musical, através das figuras de tempo e da sonoridade requerida no instrumento, influenciará as relações de contatos pontuais ou duráveis. 0 bom senso do percussionista ditará as suas considerações relativas aos diversos tipos de contatos existentes, optando pela temporalidade mais adequada de cada ação sobre 0 instrumento. Através dessa nuance interpretativa observamos a ocorrência de convergências entre as relações de contato em uma performance, permitindo a possibilidade de uma nova lista (Ex.11) contendo novas relações de gestuais (Ex.12 a Ex.22): 


\begin{tabular}{|c|c|c|c|}
\hline Tipologia do GP & Sigla & Descrição & Referência \\
\hline $\begin{array}{l}\text { Contato Direto } \\
\text { Constante }\end{array}$ & $\mathrm{CDC}$ & $\begin{array}{l}\text { Execução onde alguma parte do corpo utilizada para a extração } \\
\text { sonora estabelece contato durável (permanente) sobre o instru- } \\
\text { mento (toque preso). }\end{array}$ & $\begin{array}{l}\text { CAGE (1939). } \\
\quad \text { Ex.2. }\end{array}$ \\
\hline $\begin{array}{l}\text { Contato Direto } \\
\text { Inconstante }\end{array}$ & CDI & $\begin{array}{l}\text { Execução onde alguma parte do corpo utilizada para a extração } \\
\text { sonora estabelece contato pontual (não permanente) (toque solto). }\end{array}$ & $\begin{array}{l}\text { PIRES (1971). } \\
\text { Ex.3. }\end{array}$ \\
\hline $\begin{array}{l}\text { Contato Indireto } \\
\text { Constante }\end{array}$ & $\mathrm{CIC}$ & $\begin{array}{l}\text { Execução onde objetos manipulados pelo instrumentista estabe- } \\
\text { lecem contatos duráveis com o instrumento. }\end{array}$ & $\begin{array}{l}\text { GRISEY } \\
\text { (1976). Ex.4. }\end{array}$ \\
\hline $\begin{array}{l}\text { Contato Indireto } \\
\text { Inconstante }\end{array}$ & $\mathrm{Cll}$ & $\begin{array}{l}\text { Execução onde objetos manipulados pelo instrumentista estabe- } \\
\text { lecem contatos pontuais sobre o instrumento. }\end{array}$ & $\begin{array}{l}\text { OLIVEIRA (1993, } \\
\text { rev.1999). Ex.5. }\end{array}$ \\
\hline $\begin{array}{l}\text { Contato } \\
\text { Semi-Direto } \\
\text { Constante }\end{array}$ & $\operatorname{CSDC}$ & $\begin{array}{l}\text { Execução do instrumento sem haver contato direto do instru- } \\
\text { mentista sobre o material que, estando em contato constante } \\
\text { com o instrumento, extrai o som do mesmo. }\end{array}$ & $\begin{array}{l}\text { STASI (1990). } \\
\text { Ex.6. }\end{array}$ \\
\hline $\begin{array}{l}\text { Contato Semi-Direto } \\
\text { Inconstante }\end{array}$ & CSDI & $\begin{array}{l}\text { Mesmo conceito aplicado ao CSDC, salvo que o objeto que extrai } \\
\text { o som não estará em contato constante com o instrumento. }\end{array}$ & $\begin{array}{l}\text { TINOCO }(2003 \\
\text { p.03). Ex.7. }\end{array}$ \\
\hline $\begin{array}{l}\text { Contato } \\
\text { Semi-Indireto } \\
\text { Inconstante }\end{array}$ & CSII & $\begin{array}{l}\text { Uma parte do corpo percutirá sobre outra que estará manipu- } \\
\text { lando um objeto qualquer. } 0 \text { mesmo se moverá por simpatia, es- } \\
\text { tabelecendo contato com o instrumento. }\end{array}$ & $\begin{array}{c}\text { STASI (1990, } \\
\text { p.04). Ex.8. }\end{array}$ \\
\hline $\begin{array}{l}\text { Contato } \\
\text { Semi-Indireto } \\
\text { constante }\end{array}$ & CSIC & $\begin{array}{l}\text { Raspar um objeto contra outro apoiado sobre um membranofone. } \\
0 \text { instrumento atuará como um amplificador e modificador do } \\
\text { som. O CSIC se caracterizará ao considerarmos como instrumento } \\
\text { todo o conjunto dessa relação de contato. }\end{array}$ & $\begin{array}{l}\text { ZAMPRONHA } \\
(2000 / 2006 \\
\text { p.07). Ex.9. }\end{array}$ \\
\hline $\begin{array}{l}\text { Contato } \\
\text { pseudo-indireto } \\
\text { inconstante }\end{array}$ & CPII & $\begin{array}{l}\text { No exato momento da extração sonora não há qualquer contato } \\
\text { táctil do intérprete estabelecido com o instrumento ou com o } \\
\text { objeto manipulado. }\end{array}$ & $\begin{array}{l}\text { STASI (1990). } \\
\text { Ex.10. }\end{array}$ \\
\hline
\end{tabular}

\section{Ex.1: Lista de tipologias de GP.}

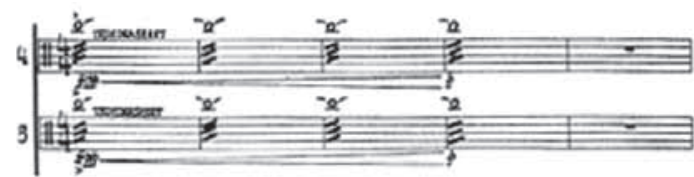

Ex.2 - First Construction (In Metal) (1939) de CAGE:

realização de tremolo na folha de zinco, segurando a mesma de forma constante (c.1-5).

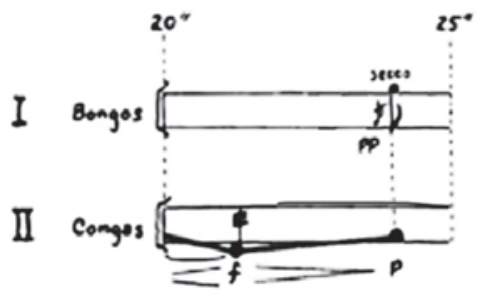

Ex.3: Pires: Ostinati (1971) de PIRES: rulo nas congas com mãos (2 Sistema).

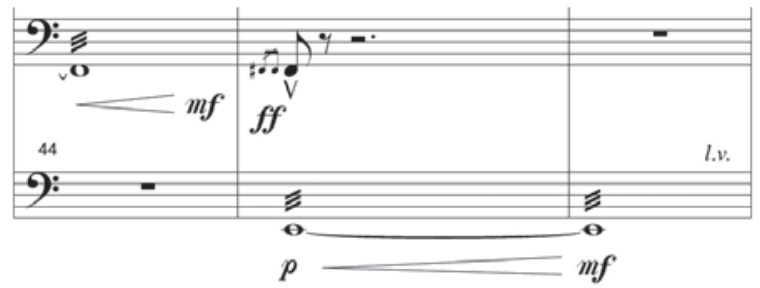

Ex.4: KYTI (1993/1999) de OLIVEIRA: rulo nos tímpanos (c.44-46). 


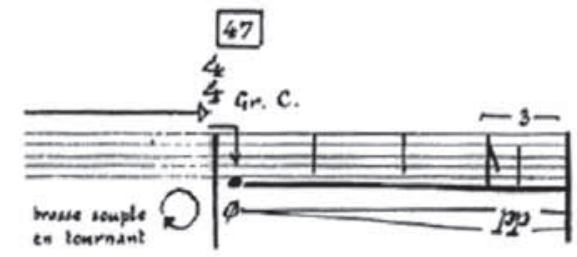

Ex.5: Partiels pour 18 musiciens (1976) de GRISEY:

raspar escova continuamente sobre a pele de um bombo sinfônico (c.47).

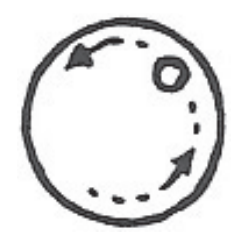

Ex.6: Canção Simples de Tambor (1990) de STASI: bola de pingue-pongue gira continuamente sobre a caixa sem o percussionista tocar-Ihe (Início do $3^{\circ} \mathrm{mov}$.).

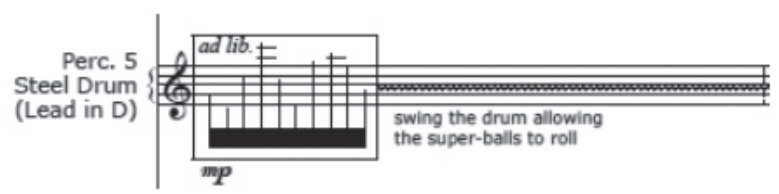

Ex.7:Imaginary Dancescape a Melodrumming after Cocteau (2003) de TINOCO: bolas de borracha sacudidas dentro de um Steel-Drum (c.5).

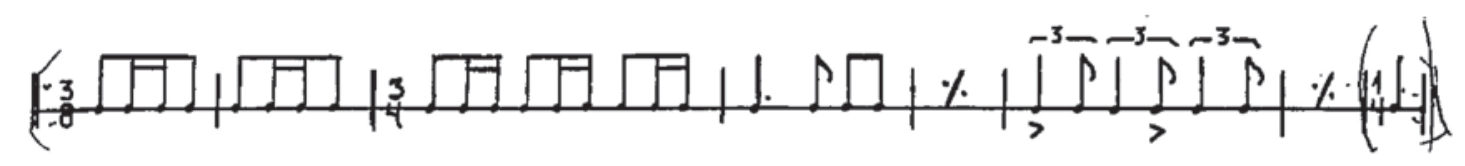

Ex.8: Canção Simples de Tambor(1990) de STASI: uma mão executa o ritmo escrito sobre a outra que está segurando uma vara de pesca (p.04).

\begin{tabular}{|l|l|l|l|c|}
\cline { 2 - 4 } Seção IV & $1: 20$ & S / D & Arranhar - variar baquetas & $(40 ")$ \\
\cline { 2 - 4 } Seção V & $2: 00$ & S & Fricção & $\left(105^{\prime \prime}\right)$ \\
\cline { 2 - 4 } Seção VI & $3: 45$ & S / NRW & Arranhar repetitivo & $(65 ")$ \\
\hline
\end{tabular}

Ex.9: Recycling Collaging Sampling (2000/2006) de ZAMPRONHA: seção de improviso, onde $\mathrm{D}=$ peles; $\mathrm{S}=$ metais suspensos e NRW = madeiras e metais abafados (p.07).

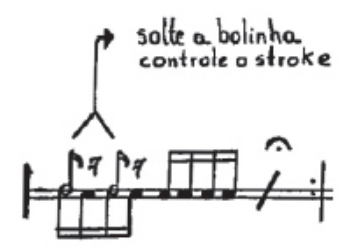

Ex.10: Canção Simples de Tambor (1990) de STASI: realizar o ritmo soltando a bola de pingue-pongue sobre a caixa e agarrando-a de volta (p.03). 


\begin{tabular}{|c|c|c|}
\hline Sigla & Descrição & Referência \\
\hline $\mathrm{Cll}+\mathrm{CDI}$ & $\begin{array}{l}\text { Manipula-se um objeto ao mesmo tempo em que alguma parte do corpo } \\
\text { está livre para percutir diretamente no instrumento. }\end{array}$ & $\begin{array}{l}\text { OLIVEIRA (2010). } \\
\qquad \text { Ex.12. }\end{array}$ \\
\hline $\mathrm{Cll}+\mathrm{CIC}$ & $\begin{array}{l}\text { Manipula-se um objeto em contato pontual sobre o instrumento e outro } \\
\text { em contato constante (g/issando em uma única lâmina). }\end{array}$ & $\begin{array}{l}\text { DEANE (1983). } \\
\quad \text { Ex.13. }\end{array}$ \\
\hline $\mathrm{Cll}+\mathrm{CDC}$ & $\begin{array}{l}\text { Manipula-se um artefacto em contato pontual com o instrumento ao mes- } \\
\text { mo tempo em que alguma parte do corpo interfere de forma constante no } \\
\text { resultado sonoro (glissando nos tímpanos). }\end{array}$ & $\begin{array}{l}\text { BARTÓK (1939). } \\
\text { Ex.14. }\end{array}$ \\
\hline $\mathrm{CIC}+\mathrm{CDI}$ & $\begin{array}{l}\text { Manipula-se um objeto em contato constante com o instrumento ao mes- } \\
\text { mo tempo em que alguma parte do corpo agirá sobre o mesmo de forma } \\
\text { direta e constante (harmônico no vibrafone). }\end{array}$ & $\begin{array}{l}\text { SEJOURNÉ (1999). } \\
\text { Ex.15. }\end{array}$ \\
\hline $\mathrm{CIC}+\mathrm{CDC}$ & $\begin{array}{l}\text { Manipula-se um artefacto em contato constante com o instrumento ao } \\
\text { mesmo tempo em que alguma parte do corpo interfere de forma constante } \\
\text { no resultado sonoro (cuíca). }\end{array}$ & $\begin{array}{l}\text { NOBRE }(1963, \text { p.35). } \\
\quad \text { Ex.16. }\end{array}$ \\
\hline $\mathrm{CDC}+\mathrm{CDI}$ & $\begin{array}{l}\text { Uma mão deverá efetuar toques constantes na pele enquanto a outra es- } \\
\text { tará apoiada em forma de concha com o cutelo encostado à pele no cen- } \\
\text { tro da mesma apontando para a mão que realiza os toques. Esse tipo de } \\
\text { contato ocorre quando deslizamos a mão que está no centro da pele em } \\
\text { direção à que realiza os toques na borda. }\end{array}$ & $\begin{array}{l}\text { APERGHIS (1981). } \\
\text { Ex.17. }\end{array}$ \\
\hline $\mathrm{CSDC}+\mathrm{CII}$ & $\begin{array}{l}\text { Deve-se estabelecer um movimento contínuo de um objeto sobre com al- } \\
\text { guma parte do corpo atuando sobre o instrumento. Somado a esse movi- } \\
\text { mento deverá ser utilizado um batente ou objeto qualquer para percutir. }\end{array}$ & STASI (1990). Ex.18. \\
\hline $\mathrm{CSDC}+\mathrm{CIC}$ & $\begin{array}{l}\text { Será o mesmo conceito de } \mathrm{CSDC}+\mathrm{CII} \text {, no entanto o batente ou objeto de- } \\
\text { verá efetuar contatos constantes. }\end{array}$ & STASI (1990). Ex.19. \\
\hline $\mathrm{CSDC}+\mathrm{CDI}$ & $\begin{array}{l}\text { Será o mesmo conceito de CSDC+CII, salvo que já não há manipulação } \\
\text { de um batente. Alguma parte do corpo deverá agir diretamente sobre a } \\
\text { extração sonora do instrumento. }\end{array}$ & STASI (1990). Ex.20. \\
\hline $\mathrm{Cll}+\mathrm{CDI}+\mathrm{CDC}$ & $\begin{array}{l}\text { Toques no Repique: Uma das mãos utiliza baqueta e a outra estará livre } \\
\text { para percutir de forma direta e indireta. }\end{array}$ & $\begin{array}{l}\text { ROSAURO (1992). } \\
\quad \text { Ex.21. }\end{array}$ \\
\hline $\begin{array}{c}\text { Combinações } \\
\text { diversas }\end{array}$ & Observadas em obras que permitem a criação de improvisos. & $\begin{array}{c}\text { STASI (1990: 03). } \\
\text { Ex.22. }\end{array}$ \\
\hline
\end{tabular}

Ex.11: Lista de combinações do GP.

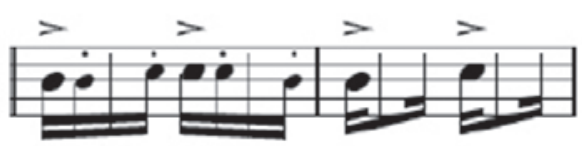

Ex.12: Radio Bossa (2010) de OLIVEIRA: notas com "cabeça" grande = polegar direito, "cabeça" pequena = dedos e baquetas, figuras sem "cabeça" = mão direita aberta (p.01).

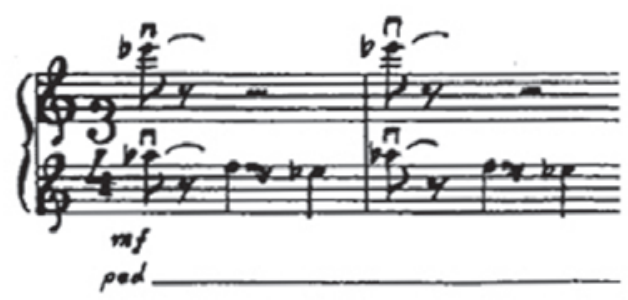

Ex.13: Mourning Dove Sonet (1983) de DEANE:.glissando de Fá para Mi bemol (c.1-2). 


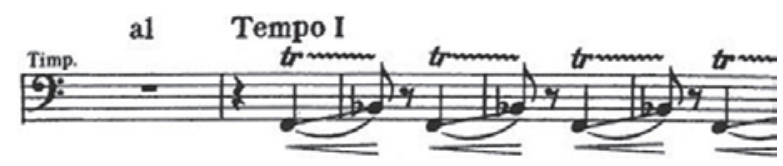

Ex.14: Sonata para dois pianos e percussão (1939) de BARTÓK: glissando nos tímpanos (c.259-263).

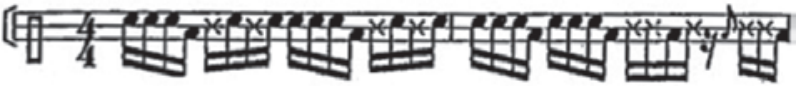

Ex.15: Rhapsody for Percussion Solo and Orchestra (1992) de ROSAURO:

Toques no Repinique (c.365-366).

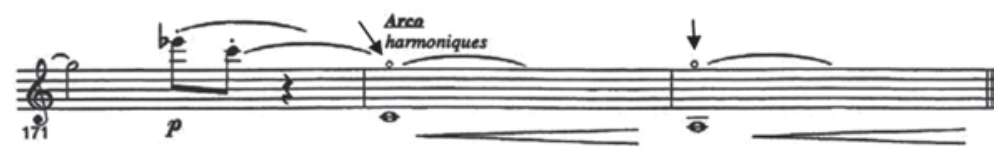

Ex.16: Concerto pour Vibraphone et Orchestre à Cordes (1999) de SEJOURNÉ: harmônicos no vibrafone em uma única lâmina, utilizando arco e dedo como artifícios (c.171-173).

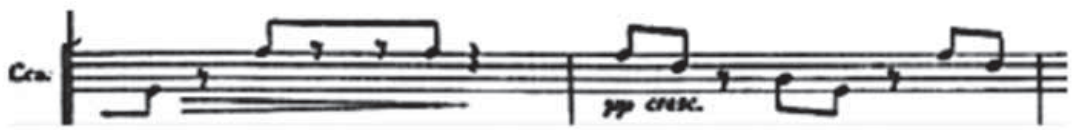

Ex.17: Variações Rítmicas (1963) de NOBRE: linha da cuíca (1º sistema, p.35).

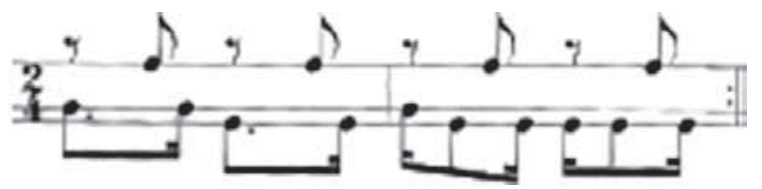

Ex.18: Exercício n.12 (2003) de BOLÃO. Toques no Rebolo onde: Voz de cima FUSTE, voz do meio DEDOS e voz de baixo MÃO (p.51).

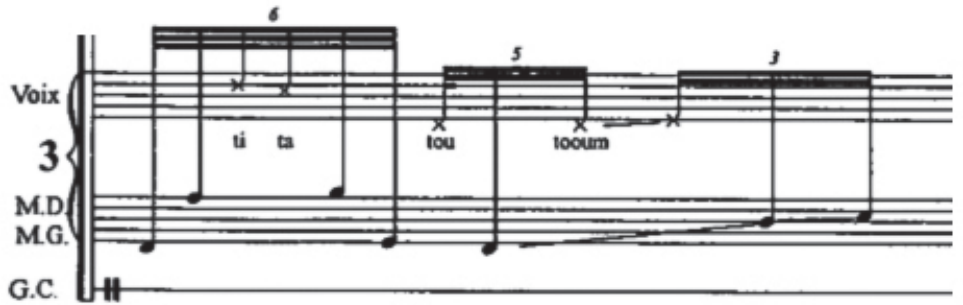

Ex.19: Les Gutteurs de Sons (1981) de APERGHIS: cotovelo apoiado no centro da pele do tambor para a realização do glissando (c.263). 


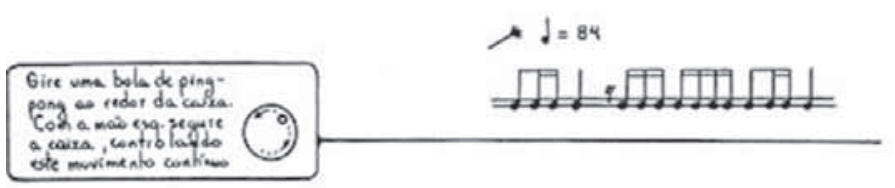

Ex.20: Canção Simples de Tambor (1990) de STASI: enquanto a bola de pingue-pongue gira na caixa, deve-se realizar o rimo escrito utilizando uma vassourinha em toques simples (p.03).

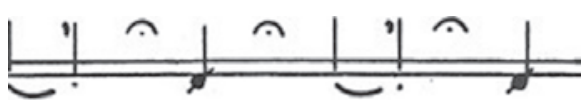

Ex.21: Canção Simples de Tambor (1990) de STASI: enquanto a bola de pingue-pongue gira na caixa, deve-se raspar a vassourinha nas figuras sem "cabeça" (p.03).

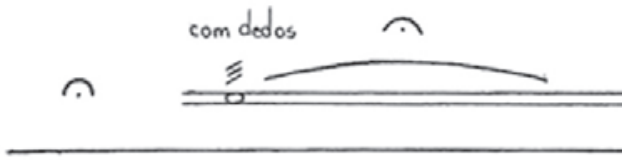

Ex.22: Canção Simples de Tambor (1990) de STASI: enquanto a bola de pingue-pongue gira na caixa, deve-se realizar um rulo com os dedos (p.03).

\subsection{Conceitualização do GP}

Após as observações realizadas a partir das listas Ex.1 e Ex.11, admitimos o GP como o movimento corporal indispensável para a primeira ação gerada entre 0 intérprete e instrumento (a sua extração sonora). De carácter puramente técnico mas não interpretativo, esse gesto será o primeiro passo dado para a construção de uma performance em percussão, podendo ser considerado a primeira fonte de interlocução expressiva do intérprete. Apesar de ser responsável pelos movimentos corporais desprovidos de interpretação musical intencional, o GP poderá estar condicionado ao primeiro fator determinante para a busca de uma expressividade corporal que interaja com a música pois: "o corpo não é, nunca, significativa e emocionalmente neutro, nem para os praticantes, nem para os observadores" (FAZENDA, 1996 p.149). GODøY também comunga dessa ideia ao afirmar no conceito de Sound-producing gestures que: [...] That serves articulation [...] and expressivity" (GODøY, 2010 p.110). No entanto o GP como fonte de expressividade não é necessariamente um ato interpretativo. Isso significa que, mesmo antes da interpretação, existe a expressão inerente do corpo ilustrada através dos simples gestos realizados pelo instrumentista para a obtenção do som. É também necessário salientarmos que, mesmo tratando-se de um gesto técnico: "O gesto entendido como pensamento não racionalizado, se mostra como a forma primordial de entendimento da atividade musical" (CAZARIM, 2008, $\mathrm{s} / \mathrm{p}$.). Ao considerarmos condição sine qua non para a prática musical percussiva, o GP será:

Movimento somático inevitável, consequente de uma execução instrumental percussiva.

\section{Gesto Percussivo Interpretativo (GPI)}

Determinar os meios de interpretação que caracterizarão os movimentos realizados com o corpo, significa efetivamente delinear e criar correspondências entre os gestos realizados e o carácter interpretativo da obra. 0 percussionista, mais do que qualquer outro instrumentista, poderá estabelecer esse paralelo ao encontrar certas possibilidades no que diz respeito às formas que o corpo pode adquirir no espaço e o tipo de sensação que as mesmas poderão passar ao espectador.

A conexão que o percussionista estabelece com o seu instrumento é bastante complexa. No repertório destinado à percussão a relação de espaço entre instrumento e instrumentista não poderá em hipótese alguma ser ignorada. Ao contrário, torna-se uma questão preponderante para a construção dos gestos percussivos. 0 intérprete tem que, antes de tudo, perceber o seu plano de espaço em relação ao instrumento que está à sua frente. No caso de uma marimba ou um vibrafone as 
aberturas das baquetas serão diferentes para os intervalos, dependendo da região do instrumento. Uma abertura de intervalo de $4^{\mathrm{a}}$ ou $5^{\mathrm{a}}$, por exemplo, nunca será igual em oitavas diferentes. Dificilmente um percussionista tocará um instrumento de lâminas ${ }^{4}$ sem mover as pernas e o tronco, modificando consideravelmente a sua posição correspondente ao instrumento. Com relação aos instrumentos de percussão múltipla o problema da relação espaço/instrumentista é ainda mais complexa pois, para cada montagem, surgirão problemas distintos:

0 intérprete, muitas vezes, se desloca no espaço e adquire diferentes posições para o seu corpo na execução de obras que requerem configuração de instrumentos com tamanhos, pesos, disposições de lâminas e alturas ${ }^{5}$ diferentes. TRALDI, CAMPOS, MANZOLLI (2008, p.03).

Percebemos como o desenvolvimento de uma memória espacial $^{6}$ torna-se imprescindivel para o percussionista construir a sua performance. Em música geralmente utiliza-se o termo memória muscular(ou memória motora) no ato da performance ou aplicada a uma metodologia de estudo do instrumento. Para o percussionista será importante pensar como um ator de teatro ou um bailarino, admitindo para si também a ideia de memória corporal, que será exatamente:

memória muscular + memória espacial = memória corporal

A importância da conscientização de uma memória corporal para o desenvolvimento e para uma boa utilização dos gestos poderá ser sentida na afirmação de Catalão: "Un musicien qui dépend trop de la vision pour jouer de son instrument aura moins de conscience de sa gestuelle et développera moins sa mémoire corporelle" (CATALÃO, 2008 p.52). Poderemos afirmar que em música o performer deverá referenciar a sua memória corporal à sua memória auditiva, caso contrário o resultado final poderá tornarse excessivamente coreográfico, escasso de material musical. 0 resultado que esperamos da memória corporal é a realização de uma execução instrumental condizente com o conteúdo musical que se queira transmitir. Para considerarmos exequível uma performance musical em instrumentos de percussão nos termos descritos, as pernas, as mãos, os pés e o tronco do corpo humano tornam-se tão essenciais quanto os braços e a cabeça. Em muitos casos, isso gera a ideia de uma "intrigante e sutil dança" (TRALDI, CAMPOS, MANZOLLI, 2008 p.03). Para concebermos essa ideia torna-se relevante a preocupação com os movimentos realizados pelo tronco e membros inferiores. Sem o auxílio dessas partes do corpo se tornariam praticamente impossíveis performances sobre obras de primeira grandeza do repertório a exemplo de Zyklus(1951) de STOCKHAUSEN, Janissary Music (1962) de WORRIEN ou Psappha (1979) de XENAKIS.

Admitimos que, para a grande maioria das obras escritas para percussão, os braços e os pulsos serão importantes para conduzir as mãos à extração do som do instrumento. Mas devemos também constatar que os movimentos realizados com as pernas, os pés e o tronco do intérprete ampliarão as suas possibilidades para uma execução instrumental mais eficaz. É possível evidenciarmos isso bem claramente nas montagens feitas para a execução de obras que envolvem percussão múltipla, onde a inutilização dos membros inferiores e tronco tornaria bastante limitada a execução instrumental e os possíveis meios de interpretação e expressividade.

Observando os instrumentos de lâminas percebemos uma movimentação de tronco e membros inferiores essenciais para o instrumentista estar devidamente colocado frente a uma região qualquer do instrumento. Em diversos casos no vibrafone faz-se necessária a alternância dos pés sobre o pedal, o que influencia diretamente em um "jogo" de pernas e movimentação do tronco: "Os dois pés devem ser utilizados alternadamente, conforme a região do instrumento executada, contribuindo para um posicionamento corporal adequado diante do mesmo" (CHAIB, 2012 p.62).

\subsection{Gesto e Exercício Intelectual}

Segundo ZIBIKOWSKY (2011) todo gesto que acompanha um discurso (em termos de linguagem falada) é responsável por introduzir novas informações às estruturas do discurso. 0 autor sugere que através das análises realizadas sobres estudos de MACNEIL (2005) é possivel chegar-se a duas importantes conclusões. A primeira indica que o gesto oferece dinamismo ao discurso, sendo uma fonte imagística de pensamentos dificeis de serem expressados (ou que se tornam incômodos) através da linguagem falada. A segunda conclusão (e possivelmente a que melhor se aplicará na transposição para a performance musical em percussão) diz respeito ao fato de os gestos, através do pensamento, informarem e darem forma ao uso da linguagem. Num processo interpretativo é exatamente esse o caminho que procuraremos seguir para a construção da performance percussiva. 0 gesto pensado para a execução musical poderá ajudar a transmitir a nossa ideia do conteúdo musical a ser transmitido.

Para falarmos sobre o gesto numa perspectiva intelectual agregada ao plano artístico torna-se necessário observar a origem de onde partem esses movimentos e a intencionalidade dos mesmos, pois: "Apenas quando o movimento, que foi inicialmente um gesto genuíno, é executado a partir da imaginação, pode tal gesto se tornar um elemento artístico [...]" (LANGER, 1953 p.175). Percebemos que a realização de um gesto que não possui no seu ponto de partida a origem de um trabalho racional, será incapaz de transmitir qualquer significado artístico. 0 intérprete, através do gesto intelectual (GIL, 2001), deverá reagir a diferentes situações criando diversas alternativas corporais para distintos trechos ou passagens. Esse gesto, por ser abstrato, poderá ser visualizado através do corpo uma vez que: "Todo o pensamento [...] é acompanhado de gestos virtuais que o próprio pensamento não é capaz de exprimir, o que exigem um corpo para se poderem dizer", (GIL, 2001 p.220). É dessa 
forma que a ação do seu pensamento deverá, de alguma maneira, permitir-se sentir (visivel ou sonoramente), transformando-se necessariamente numa aproximação interpretativa entre a obra e o público. No seio desse conceito habita o exercício intelectual e a atitude de pensar do intérprete. É possível que a carência de uma prática racional do intérprete na forma de construção dos seus gestos possa gerar, em clara evidência, um suposto distanciamento entre o executor, a obra e a plateia pela falta de elementos artísticos capazes de estabelecer uma interação comunicativa entre artista e espectador.

LABAN (1978) afirma que o espaço será um fator de movimento que também interferirá no pensamento ${ }^{7}$ (enquanto raciocínio lógico) do intérprete. 0 autor sugere a existência de quatro fases do esforço mental que precedem e acompanham ações propositadas, sendo elas: atenção, intenção, decisão e precisão. 0 movimento relativo ao espaço encaixa-se na fase de atenção. A tendência será o performer buscar uma auto-orientação criando uma relação com um objeto de interesse de modo direto e imediato ou de forma prudente e volúvel. A intenção determinará a tensão muscular depositada sobre a ação, graus de força, variando entre o leve e o pesado. A decisão é talvez o momento mais intuitivo de toda a ação pois refere-se ao tipo de gesto realizado (por exemplo de que maneira o performer deverá estender ou não o braço, se faz ou não sentido naquele exato momento o movimento pensado). A precisão será o fator que antecede brevemente à ação objetiva. 0 controle das outras fases será determinante para que esse fator se relacione ao movimento de forma congruente à execução da ação pensada. Precisão será o próprio domínio do movimento bem estudado.

Em música para percussão tudo parece ser volúvel e não exato. 0 fator decisão altera-se em diversos níveis quando observamos diferentes performances de uma mesma obra realizadas pelo mesmo intérprete. Por questões de coerência e logística fomos obrigados a realizar duas montagens distintas para a execução de Phènix (1982) de BERNARDMÂCHE8. Outro exemplo será a alteração da afinação das pedras em Três Quadros sobre Pedra (2011) de ANTUNES PENA $^{9}$. Mesmo no procedimento de composição da performance, 0 intérprete utiliza a sua própria visualização (e do espaço em torno de si) como um artifício para memorizar mais facilmente os movimentos adquiridos para a execução instrumental. Daí um dos pontos preponderantes onde o gesto relacionado ao exercício intelectual deve ser assumido como um elemento fundamental para a performance em percussão. A discussão travada sobre a proficiência metafórica do movimento corporal no sentido de comunicar-se levou PIKE à seguinte conclusão:

É impossivel determinar com precisão a fronteira que separa um fragmento de outro; de dizer exatamente onde um segmento acaba e onde começa o seguinte; a primeira razão desta indeterminação é que os movimentos do corpo, deslizam ou correm de um para outro, de tal modo que é muitas vezes impossivel cortar o continuum [...]. PIKE (1967, p.77).
Catalisar esse procedimento comunicativo metafórico entre os movimentos do corpo e a música poderá nos ajudar a reduzir as dificuldades colocadas por PIKE. No momento em que o autor afirma ser "impossível dizer exatamente onde um segmento acaba e onde começa o seguinte", nós sugerimos como apoio para a solução desse problema a utilização da estrutura da obra musical. No momento que os movimentos acompanharem a ideia sonora da performance (tenha ela momentos de silêncio ou não), as duas formas de expressão automaticamente serão capazes de compensar as lacunas uma da outra.

\subsection{Quebra com a natura}

Se atribuirmos o fato de que a interpretação é também fruto de um exercício intelectual, onde o pensamento está interagindo diretamente com questões abstratas e concretas, a relação estabelecida do corpo com qualquer processo natural parece revelar-se como um elemento sem relação ao ato interpretativo de uma obra (por exemplo, o simples ato de apalpar algum instrumento sem intencionalidade técnica ou musical). Ou seja, para haver uma intenção artístico-musical sobre o gesto aplicado no instrumento, o mesmo deve ser pensado anteriormente como um elemento comunicativo de expressão artística. Se não houver um trabalho intelectual de formação da interpretação e expressividade, o gesto como elemento artístico comunicativo perder-se-á.

É importante não confundirmos conceitos e aceitarmos, principalmente no que tange a performance em percussão, a ideia de que os movimentos possam vir a ser fenômenos "naturais". A expressão "natural" pressupõe algo inerente ou, sob certo ponto de vista, um sentido de normalidade. No gesto natural o corpo se desloca no espaço devido à imposição exterior da ação. Quando realizamos a ação de caminhar, movimentamos as pernas e os pés instintivamente devido à necessidade de locomoção. Não há um movimento cadenciado ou a presença de um ritmo que denuncie o controle interno do movimento e, quando há, deixa de ser natural (por exemplo a marcha de um batalhão de soldados). A respiração é outro exemplo. Quando respiramos de forma inerente, nem damos conta desse ato por ser tratar de algo natural. Mas quando trabalhamos a respiração para a prática de um desporto, execução de um instrumento de sopro ou mesmo cantar, deixamos de agir naturalmente, evidenciando-se uma cadência rítmica.

Em diversos casos a movimentação do percussionista sobre o instrumento não possui qualquer elemento que o caracterize como algo natural. Ao contrário, por muitas vezes exige-se um certo esforço físico, equilíbrio e metodologia de estudo onde são necessárias inúmeras repetições do mesmo movimento para que ele se torne exequível. Não se tratam apenas de repetições de um gesto para a resolução de um problema que envolva passagens musicais tecnicamente difíceis. 0 que está escrito na partitura pode não necessariamente implicar dificuldade, mas a movimentação corporal que permite o melhor 
posicionamento do instrumentista sobre o instrumento é que pode gerar certo desconforto, justamente por não se tratar de algo natural. A partir do momento que fazemos uma certa associação entre a dança e os movimentos corporais do percussionista, devemos presumir e assumir que os mesmos não são, de todo, naturais:

0 ato de dançar, em qualquer que seja a situação, é indissociável das técnicas corporais através das quais o corpo e o seu movimento se constroem formal e significativamente, pelo que a atuação do corpo na dança não é um fenômeno natural. FAZENDA (1996, p.141).

Obviamente o percussionista ou qualquer intérprete ao preparar uma determinada obra fará o possível para tornar a execução o mais natural possivel aos olhos do espectador. Para nós toda a dificuldade motora impingida no processo de criação da performance justifica a antenaturalidade dos movimentos lançados em palco. Não é uma regra geral, mas tão-pouco pode-se afirmar que os movimentos interpretativos para a execução de um instrumento de percussão sejam, de todo, naturais. Dentro de uma outra perspectiva o conceito de corpo "natural" está associado a outras ideias, dentre elas a espontaneidade e universalidade de movimentos: "[...] funcionamento 'natural' do corpo, o seu movimento deve ser espontâneo, livre das regras que se rege a construção de um corpo artificial" (FAZENDA, 1996 p.147). Nesse sentido admitimos o movimento "natural" (como a autora coloca, entre aspas) do corpo do intérprete na sua relação espontânea com a música, nesse caso com a improvisação musical. Não descartamos a possibilidade de 0 percussionista encontrar recursos corporais instintivos e se valer dos mesmos para a realização de uma performance musical improvisada. De outro modo torna-se difícil admitir como a "naturalidade corporal" poderia ter relação com a performance percussiva, ou mesmo musical. Por outro lado, é precisamente pela improvisação que se poderá perceber a falta de naturalidade encontrada nos movimentos. Acreditamos que futuros trabalhos poderão vir a demonstrar gestos jamais pensados ou realizados.

Expressar a composição do gesto corporal na performance do percussionista poderá nos induzir a afirmar que a fluência de um determinado movimento não deva transgredir a naturalidade do mesmo. Mas aqui o sentido de "naturalidade" significa não romper e nem se sobrepor gestualmente à construção do texto musical. 0 nosso cuidado deverá ser destacar que a concepção do gesto corporal não pode e nem deve ser algo exagerado, sem sentido, além daquilo que se espera dos movimentos corporais relativos a uma performance musical.

\subsection{Exemplos no repertório}

$0 \mathrm{GPI}$ também evidencia-se numa perspectiva anterior à performance em palco. As reflexões relacionadas à representatividade do material sonoro fará da interpretação uma componente gestual abstrata que se transmodificará para o corpo e para o instrumento. Observando as obras para percussão percebemos que para além das diferentes interpretações que uma composição permite em termos gerais, o repertório diferencia-se principalmente pelo fato de poder gerar, em cada performance, um material sonoro completamente diferente mantendo-se a estrutura da obra. Os compositores usufruem diretamente desse conceito e oferecem ao intérprete uma possibilidade diferente de atitude desse mesmo gesto. No caso em questão um compositor poderá alterar o material sonoro proposto inicialmente em uma obra. Essa é uma particularidade, sob uma perspectiva quase ilimitada de variações sonoras, atribuída exclusivamente aos instrumentos de percussão. Será possivel alterar um ou outro instrumento (ou suprimir e/ou adicionar), modificando substancialmente o carácter musical da obra, sem contudo interferir na sua escrita e estrutura.

Para executarem-se meios expressivos como ligaduras de frase, dinâmicas e articulações a partir de um vibrafone o intérprete deverá pensar gestualmente diferente ao procurar o mesmo sentido musical em passagens que envolvam, por exemplo, instrumentos de pele ou idiofones. Os diferentes instrumentos, que exigem distintas maneiras de execução, para os quais se quer passar a mesma ideia musical farão com que o intérprete atue ao mesmo tempo com atitudes distintas. No caso de uma obra possuir um instrumento de lâmina e instrumentos de pele, madeira ou metal, o pensamento musical deverá ser o mesmo para que o carácter da obra não perca a sua homogeneidade interpretativa. Percebemos que o GPI, ao atuar em diferentes níveis ao mesmo tempo, será um gesto com uma pluralidade de atitudes possiveis de serem interpretadas e executadas em si

Para além da obra em si, o próprio instrumento e materiais a serem manipulados pelo percussionista tornam-se necessários para que o gesto intelectual traduza o significado musical desejado. A escolha do tipo de material para ilustrar um trecho ou uma obra por inteiro, influenciará a forma como vemos a performance e como ouvimos o material sonoro. Um claro exemplo será a obra Três Quadros sobre Pedra ${ }^{10}$ (2011) de Luís Antunes Pena, onde o compositor exige a presença de seis pedras previamente afinadas na montagem (Ex.23).

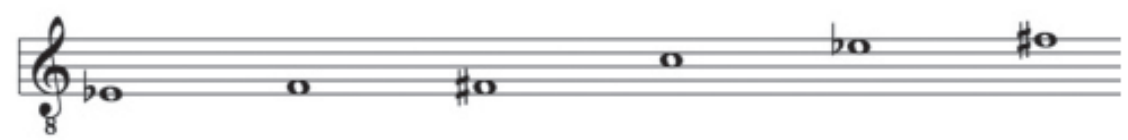

Ex.23: Três Quadros sobre Pedra (2011) de ANTUNES PENA: afinação das pedras. 
No decorrer da montagem dessa obra travamos diversas conversas informais com o compositor ${ }^{11}$. Nas pesquisas realizadas sobre as pedras (em termos de sonoridade, timbre, ressonância, etc.) descobrimos um tipo de pedra com um timbre bastante peculiar ${ }^{12}$. 0 som das mesmas agradou o compositor de tal forma que foi-nos dispensada a necessidade de encontrar as notas pré-estabelecidas na partitura. 0 receio era o de que, ao cortar as pedras para tentar afinar as notas, as suas características sonoras originais pudessem se perder. Desta forma, o material utilizado e consequentemente o resultado sonoro para a nossa performance foi diferente do material (instrumental e sonoro) sugerido nas indicações da partitura ${ }^{13}$.

Observando a obra The Anvil Chorus (1991) de David Lang percebemos a existência de quatro vozes independentes que realizam uma interlocução entre si. 0 compositor divide essas vozes através de grupos de instrumentos e materiais, além da maneira como os mesmos devem ser tocados. Pelo tipo de material sugerido e observando o título da obra podemos ter uma ligeira ideia de como a música deve soar. Em verdade, a ideia de vários ferreiros trabalhando ao mesmo tempo com batidas em pulsos e velocidades diversas é o que caracteriza a origem desta obra.

0 GPI intensifica-se no making off da performance da obra. À medida que vamos estudando percebemos quais mudanças na montagem serão necessárias. Esse momento é certamente um ato de cognição espacial e tímbrica delineado para o interprete em função da obra executada, exigindo uma conexão imprescindível com o GP. Deveremos trabalhar sobre o GPI as informações oferecidas pela obra para desenvolvermos a ideia sonora onde o instrumento de percussão múltipla moldado (resultante desse gesto) oferecerá ao intérprete e ao ouvinte. 0 compositor separa os grupos de metais em ressonantes e não ressonantes. Mas, da mesma forma que SCHICK (2006), podemos considerar uma terceira via que seria a dos metais semi-ressonantes. Desta maneira permitese que as vozes estejam mais claramente distribuidas, podendo-se ouvir com eficácia as poliritmias escritas. Não nos vemos obrigados a seguir um padrão e estipular o mesmo tipo de material para cada voz (pelo menos para as vozes dos metais). Basta que sejam ressonantes, semi-ressonantes e não ressonantes. As diferentes ressonâncias e intenções de toque ditarão a independência das vozes, podendo o percussionista optar por uma montagem com grande diversidade tímbrica. No Ex.24 estão listados os instrumentos que fizeram parte da nossa montagem.

Dificilmente, quando se trata de uma obra que dá certa liberdade de escolha dos instrumentos, o percussionista "acerta" na montagem em uma primeira experiência. 0 resultado tímbrico final ouvido pelo espectador será fruto de um forte exercício intelectual no decorrer do preparo da obra. Estando os instrumentos escolhidos, faz-se necessário definir a melhor forma de dispô-los diante do intérprete, tendo em conta que esta obra assume a peculiaridade do uso de cinco pedais. Para atenuar as dificuldades técnicas impostas pela obra optamos por tocar sentado. Começamos a construir a montagem a partir dos instrumentos a pedal. Dispomo-los entre $140^{\circ}$ e $160^{\circ}$, sendo os metais mais graves tocados com o pé esquerdo e os mais agudos com 0 direito. 0 bombo estará situado entre as duas enxadas.

Os instrumentos do Grupo 2 e 3 estão acomodados sobre uma pequena mesa, permitindo a locomoção dos pés por debaixo da mesma, para a execução dos pedais. Os três metais do Grupo 1 estarão suspensos sobre a mesa e defronte ao intérprete, este estará sentado em uma posição central à montagem (Ex.25):

\begin{tabular}{|l|l|}
\hline Grupo 1 & mola de elevador (agudo), frigideira grande (médio), cano cilíndrico longo (grave). \\
\hline Grupo 2 & Quatro canos de metal retangulares de diferentes procedências e alturas distintas. \\
\hline Grupo 3 & Dois blocos de madeira bastante sonoros (médio e agudo). \\
\hline Grupo 4 & latão de petróleo (grave), lata de tinta (médio), duas enxadas (agudos), bombo de 20'. \\
\hline
\end{tabular}

Ex.24: The Anvil Chorus (1991) de LANG: instrumentos da montagem.

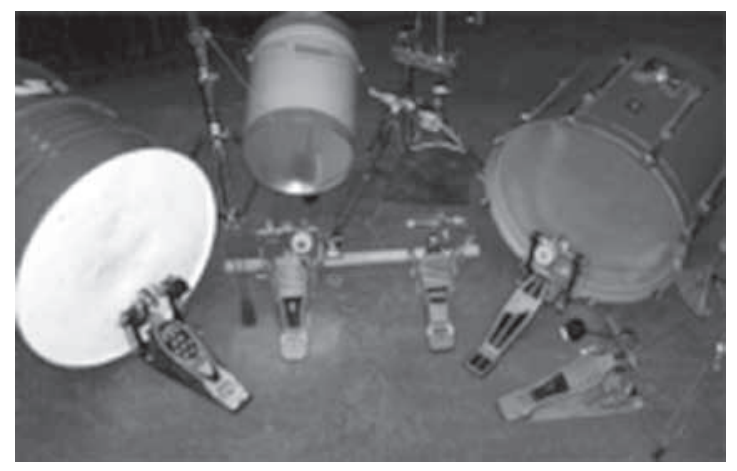

Ex.25: The Anvil Chorus (1991) de LANG: parte da montagem (instrumentos à pedal). 


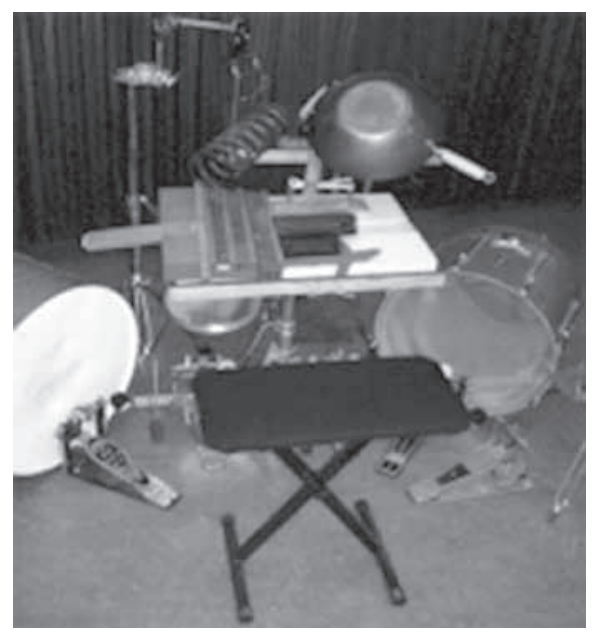

Ex.26: The Anvil Chorus (1991) de LANG: montagem completa.

Mediante os estudos vão avançando passamos a saber o tipo de relação angular e de distância que os instrumentos devem ter entre si para uma melhor performance. Outrossim esse gesto também pode traduzir-se na própria montagem mesmo antes de chegarmos aos movimentos corporais. 0 material usado para percutir pelo percussionista poderá ajudar a traduzir a mensagem a ser passada: "The set of instruments needed to represent this much independent rhythmic material is a percussive junk-heap, a mousetrap contraption featuring five foot-pedals and handfuls of noisy percussion instruments" (SCHICK, 2006 p.27). Quando assumimos a figura de ferreiros para a obra, podemos criar a possibilidade de uma visualização bastante aproximada dessa ideia. Foi possivel admitir para a mão esquerda, durante as intervenções sonoras dos metais não ressonantes, o uso de um martelo. 0 timbre adquirido por essa ferramenta sobre os metais (contribuindo para o efeito sonoro proposto) e a sua visualização (através do seu formato, como referência laboral numa cultura), permite ao público "separar" as vozes de modo visual e auditivo, sendo possivel identificar as diferentes "personagens" que o percussionista interpreta de maneira independente durante a sua performance. 0 compositor chega a sugerir o uso de martelos de sinos tubulares para os metais ressonantes, mas os instrumentos escolhidos para esta voz resultaram melhor sonoramente com outro tipo de batente. Fica estabelecido para a mão direita o uso de uma baqueta com uma cabeça grande extremamente dura (usada para os metais ressonantes e blocos de madeira), um martelo comum de pequeno porte na mão esquerda para os metais não ressonantes. Para os pés utilizaremos pedais com diferentes batentes (plástico duro ou metal para o tambor de petróleo e enxada média, feltro duro para a lata de tinta e bombo, cabeça de metal para enxada aguda).

Observamos como um dos objetivos do GPI formou-se aqui através de um dispendioso trabalho de observação, paciência, estudo e esforço físico. Sendo invisível para público, por tratar-se de uma atitude tomada anteriormente à performance, será perceptivel apenas 0 seu resultado final: concreto mas inerte (a montagem); abstrato porém fluido (a música). Trata-se efetivamente de uma particularidade atribuída à música para percussão. Diremos então que o GPI será:

\section{Ações racionalizadas pelo percussionista anteriormente e/ou no ato da performance, \\ ilustradas pelas referências materiais e sonoras em palco}

\section{Gesto Percussivo Expressivo (GPE)}

Para CAMURRI e MOESLUND (2010) o gesto expressivo em música e dança:

It is responsible for the communication of a kind of information (what we call expressive content) that is different and in most cases independent, even if often superimposed on, a possible denotative meaning. CAMUURRI e MOESLUND (2010, p.253).

De acordo com os autores o conteúdo artístico expressado pelo corpo poderá ser utilizado para despertar estados mentais, sentidos, modos, afetos e intenções emocionais. De fato, essa será a principal meta do GPE: procurar induzir no espectador uma percepção musical, através dos gestos realizados pelo intérprete durante a performance, utilizando como principal fonte de interlocução o estímulo visual.

Para uma melhor compreensão de como as aplicações do GPE poderão se enquadrar na performance em percussão, estabelecemos um paralelo com a dança por se tratar de uma forma de expressão artística onde o intérprete vale-se de todo o seu corpo para a transmissão da sua mensagem sem contar com o auxílio da fala, principal via comunicativa do ser humano. 0 coreógrafo e o bailarino necessitam criar condições metafóricas que liguem os movimentos corporais às mensagens que se queiram transmitir, na maioria das vezes, em conjunto com a música. Costumam chamar à "construção" do corpo 
(preparação da coreografia) de partitura corporal. Aqui os gestos poderão alternar-se (ou fundirem-se) entre o concreto (corpo) e o abstrato (exercício intelectual) para a transmissão dessas mensagens. Salientemos que um mesmo gesto poderá ser executado pelo intérprete (e captado pelo público) com atitudes diferentes. 0 resultado final gestual poderá derivar das atitudes vinculadas ao gesto: "A compreensão do movimento vem por intermédio da descoberta das atitudes que prevalecem em relação aos fatores de movimento, ou estão ausentes, numa dada sequência de movimentos" (LABAN,1978 p.170).

Em percussão o sentido musical de uma obra torna-se muitas vezes utópico ou metafórico. Procuraremos, através do GPE, possibilitar a observação de uma diferença (ou semelhança) de carácter entre uma passagem e outra de uma determinada obra. Em muitos casos esse gesto poderá se transmodificar para qualquer região do corpo do intérprete. Não é difícil observarmos composições onde se exigem situações performativas inexequíveis ou extremamente não funcionais para o percussionista. Muitas vezes isso obriga-o a passar para o público o seu pensamento musical, a sua ideia interpretativa, de uma forma metafórica ou abstrata. No que tange às questões sonoras, os instrumentos de percussão possuem diferentes limitações no que diz respeito aos recursos musicais expressivos capazes de serem extraídos dos mesmos (como o caso de ligaduras de frase, notas longas, legatos e staccatos, variações de dinâmicas; etc.). 0 GPE será 0 responsável por atribuir ou contribuir para a transmissão de uma veracidade a supostas utopias ou metáforas existentes em certas obras existentes no repertório percussivo.

A ideia será explorar na performance sensações de expressividade possíveis de serem desenvolvidas pelo corpo em detrimento de uma obra musical. Utilizaremos como referência o conceito em dança denominado volume: "todo o movimento descreve no espaço um volume" (BOUISSAC, 1973 p.176). 0 intérprete deverá criar formas lineares com o corpo no espaço em que se encontra com o sentido de fazer-se acompanhar o trecho musical executado.

BLOM e CHAPLIN (1989) admitem que as formas lineares que podemos criar corporalmente demonstram um contraste distintivo em suas implicações dramáticas. 0 delineamento de intenções variáveis sobre linhas diretas, angulares e curvas causará, no espectador, implicações sensoriais que o levarão a distintas interpretações de fluidez ${ }^{15}$. LABAN (1978) afirma que o fator de movimento-fluência desempenha um papel fundamental em toda a expressão pelo movimento. Dar forma ao corpo no momento da performance acarreta uma dupla função: um processo de desenvolvimento do material executado e um processo de fornecimento de uma estrutura. 0 conceito de sound-accompanying gestures poderá ser perfeitamente aplicado nessa situação: "sound-accompanying gestures are not involved in the sound production itself, but follow the music [...] They can be sound-tracing [...] or they can mimic the sound- producing gestures" (JENSENIUS et. al., 2010 p.24).

O GPE surgirá na performance do percussionista exatamente nos momentos de "silêncio", suspensões, notas longas atribuídas a articulações pontuais (não envolvendo rulos, arcadas longas ou algo do gênero). $\mathrm{Ou}$ seja, circunstâncias às quais denominaremos ausência de intervenção sonora do intérprete. Uma vez caracterizado dessa forma, diremos que esse gesto não terá relação direta com a produção, mas sim com o acompanhamento dos eventos sonoros realizados, sendo uma ferramenta de estímulo visual. Para CATALÃO (2008) por exemplo:

Les moments de silence entre deux gestes musicaux espacés dans le temps doivent être remplis par les gestes physiques aptes à les relier: par exemple les mouvements fluides peuvent tracer dans l'air le chemin entre deux événements musicaux qui se suivent dans le discours musical. CATALÃO (2008, p.57).

Por estarmos cientes que a performance para 0 percussionista possui características únicas que permitem ao intérprete a construção com o seu corpo de gestos particulares ao fazer musical, percebemos como a utilização das formas lineares no corpo são claramente identificáveis e exequíveis no repertório destinado à percussão. Relacionar a dança com a performance percussiva parece-nos o mais conveniente. Ao falar sobre a relação de música e dança, John Cage afirma o seguinte:

Cualquiera que sea el método usado para componer, los materiales de la danza pueden extenderse a la organización de los materiales musicales. [...]. La música será entonces algo más que un acompañamiento, será parte integral de la danza. CAGE (2007, p.88).

Neste caso consideraremos também a reciproca verdadeira, sendo a dança também um elemento e/ou parte integral da performance musical. Assim, tomamos como procedimento análogo o seguinte conceito:

Curved and circular lines, still or moving, produce a sense of flow and ongoingness and are affined with sustained timing. They are graceful and lyrical, emphasizing a feeling of resiliency [...]; reflecting an attitude of caring $[. .$.$] they are soothing [. .$.$] , yielding,$ bending, animalike, organic. Straight lines and angles give a feeling of stasis, stillness: when done in movement, the movement appears broken or shattered and cuts through the space, there is a affinity with percussive timing. [...] They call to mind strong adjectives and their corresponding themes and ideas: hard-edged, sharp, jagged, rigid. They are unyielding, inflexible, solid. BLOM e CHAPLIN (1989, p.37-38).

Algo importante neste conceito, que será determinante para a aplicação na performance em percussão, será a relação que se faz entre as formas lineares e o tempo. É preciso salientar que em dança a expressão tempo poderá ter relação direta com o ritmo (denominado por Laban tempo-ritmo). Os autores estipulam uma diferenciação entre "tempo em suspensão" e "tempo percussivo". Por acreditarmos que os dois exemplos de "tempo" encaixam-se perfeitamente na qualidade de eventos sonoros percussivos, faremos uma releitura que nos permita interpretar as distintas situações que possam ocorrer durante a performance. A 
expressão "tempo em suspensão" passa-nos a ideia de tratarem-se de sons longos, contínuos, constantes. Já "tempo percussivo" compreendemos tratarse de uma assimilação aos ataques e articulações ritmados, em curtos espaços de tempo: "A média que permitimos a um movimento suceder a outro é a velocidade com a qual agimos". (LABAN, 2008 p.73). A simples observação do ato de andar poderá servir como exemplo, se substituirmos a ação do passo pela de tocar. Quando caminhamos de maneira natural podemos considerar esse ritmo como uma velocidade média do nosso andar. Ao atribuirmos a cada passo uma unidade correspondente a uma batida da pulsação que transmitimos poderemos determinar os graus de velocidade dos mesmos. Se dermos um passo no espaço de várias batidas, consideraremos o mesmo como lento ou vagaroso. $\mathrm{Na}$ contramão, vários passos dentro de uma só batida serão percebidos como passos rápidos.

No caso de um trecho musical onde não haja quebras e/ou características estáticas, sugerimos que o tempo de movimentação do corpo deverá seguir o tempo de duração de um evento sonoro até o outro, o que vem significar: tempo lento, movimento corporal lento; tempo rápido, movimento corporal rápido. Esta ideia poderá ser posta em causa em situações peculiares onde a "quebra" intencional do corpo perante o material sonoro produzido é um objetivo da performance. 0 que queremos dizer é que seguir 0 tempo dos eventos sonoros não será necessariamente uma regra geral, mas por outro lado poderá funcionar como um bom mecanismo de transmissão e fusão da mensagem musical a ser passada.

\subsection{Utilização das Formas Lineares}

Para visualizarmos em certos trechos da partitura as formas lineares que proporemos para a movimentação corporal durante a performance, realizamos uma simples relação visual da linha em conformidade à forma gestual passivel de ser aplicada (Ex.26).
Salientamos que todas as sugestões de construção gestual com corpo que serão apresentadas são resultado da nossa interpretação referente à composição musical executada e procura, sob nosso ponto de vista, transmitir o conteúdo da obra de maneira mais eficiente ao espectador. Não significa de todo que as propostas de movimento corporal que serão ilustradas representam uma forma única e exclusiva de gerenciar o trabalho do corpo referente à obra em questão e seu conteúdo musical. Não cabe a nós e nem é nosso intuito sistematizar e/ou tornar pragmáticas as possibilidades de performance corporal em relação a uma composição ou sobre as possiveis interpretações que surgem no ato da execução. 0 que apontaremos no decorrer desse tópico são possibilidades, caminhos que o intérprete poderá se valer para potencializar os conceitos ilustrados sob diferentes perspectivas e aplicá-los em diversas obras do repertório percussivo.

\section{a) Assimilação e convergência de textos musicais semelhantes com eventos sonoros discrepantes:}

Uma das características da obra Phènix ${ }^{16}$ (1982) de BERNARD-MÂCHE, é possuir textos musicais semelhantes para instrumentos com características sonoras completamente distintas, inseridos na composição. Para ilustrarmos a utilização de formas lineares com o intuito de estabelecer uma conexão gestual entre textos musicais semelhantes, utilizaremos dois trechos onde situa-se o tema principal da obra. Os mesmos encontram-se em lugares diferentes na partitura (um no início da composição e outro no início da segunda página). 0 intérprete, ao executar duas notas longas (mínimas pontuadas) seguidas de um ornamento no vibrafone (Ex.28), executa esse mesmo motivo no momento em que os instrumentos de pele aparecem pela primeira vez (Ex.29).

Um instrumento de pele de poucas dimensões é incapaz de sustentar por muito tempo o decaimento do som extraído por um único ataque ${ }^{17}$. Será sonoramente

\begin{tabular}{|l|l|l|}
\hline \multicolumn{1}{|c|}{ Linha } & Resultado linear do trecho \\
\hline Curva ou Circular & & \\
\hline
\end{tabular}

Ex.27: Tabela das formas lineares para serem visualizadas na partitura. 
identificável que a mínima pontuada do vibrafone (Ex.28) soará de maneira mais uniforme do que nos instrumentos de pele aqui utilizados (Ex.29). Independente do gesto de ataque que fizermos sobre o vibrafone, basta a barra de abafamento não estar encostada às lâminas para termos o som completo da nota em questão ${ }^{18}$. Algo de semelhante ocorre nas peles, pois qualquer que seja o gesto que se realize o som sempre será mais curto, neste caso, que o do vibrafone. 0 compositor sugere uma situação congénere entre o tempo de decaimento das notas dos dois instrumentos ao modificar as dinâmicas a serem executadas nas peles. Será forçoso encontrar uma alternativa que denuncie a proximidade discursiva entre esses dois trechos, para além do material sonoro do qual dispomos. A forma linear ilustrada pelo gesto atuará aqui como a fonte da solução transposta para o corpo.

Enfatizar a ligadura de frase em Ex.28 e, ao mesmo tempo, a longa duração das notas a serem executadas em Ex.29 nos conduz a uma aplicação da forma linear curvilínea ou circular. Procuraremos transmitir uma sensação de continuidade, sendo possivel estabelecer uma convergência visual no gesto executado nos diferentes eventos sonoros $e_{\text {, consequentemente, }}$ nas frases. Os movimentos compartilham elementos intencionais comuns, logo em uma frase será possivel ilustramos a sua forma e seu conteúdo. 0 espectador poderá identificar com mais facilidade a mesma ideia, passada por distintos instrumentos, ao perceber que as intenções gestuais foram as mesmas. Nesse caso o gesto demonstrará a mesma intencionalidade de execução através do corpo, contribuindo para a homogeneidade discursiva. 0 intuito será o de criar um sentido gestual para conseguirmos extrair em distintos instrumentos um conteúdo interpretativo com níveis de expressividade distintos, preservando a unidade do texto musical apresentado (Ex.30 e Ex.31):

Os Ex.30 e Ex.31 indicam o movimento curvilíneo (através da visualização das linhas curvas) realizado pelos braços em conjunto com os pulsos para a execução destes dois trechos. Conseguimos aqui construir a relação gestual interpretativa do corpo em função do trecho musical executado. Não será, de todo, necessário que os toques realizados nas peles sejam idênticos aos toques no vibrafone (ou vice-versa) pois, na sua particularidade,

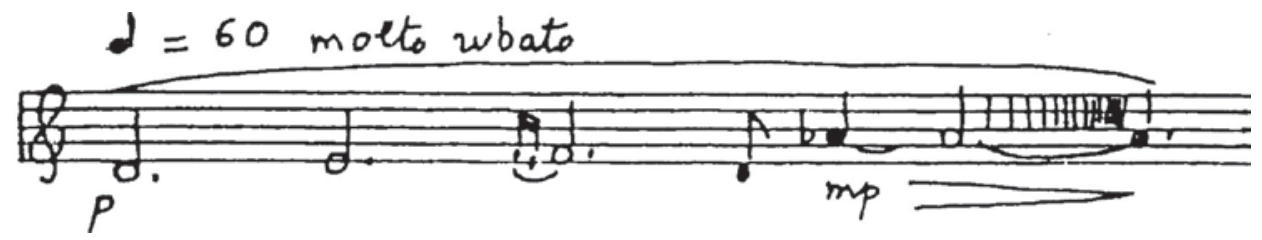

Ex.28: Phénix (1982) de BERNARD-MÂCHE: início da obra (p.01).

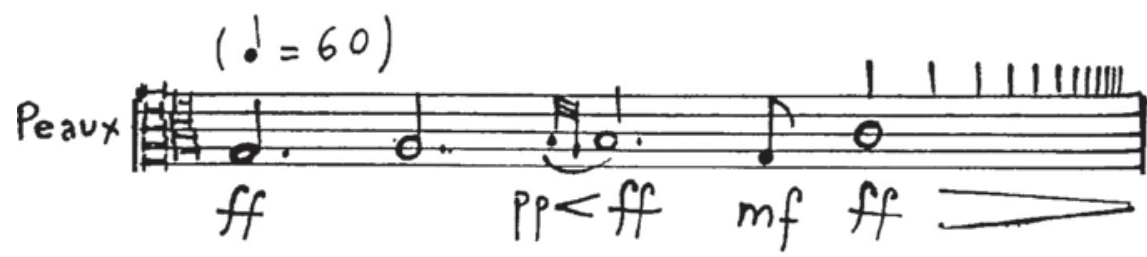

Ex.29: Phénix (1982) de BERNARD-MÂCHE: início do 10 sistema (p.02).

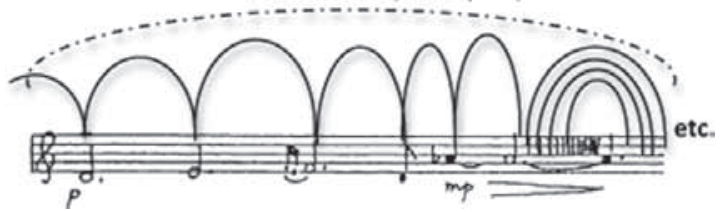

Ex.30: Phénix (1982) de BERNARD-MÂCHE: início da obra (p.01).

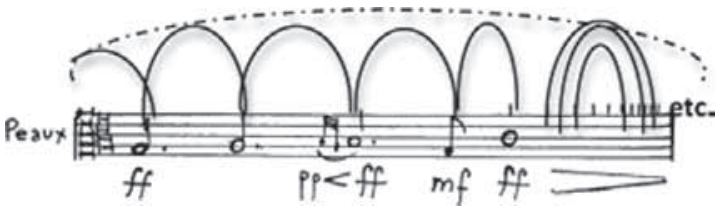

Ex.31: Phénix (1982) de BERNARD-MÂCHE: início do $1^{\circ}$ sistema (p.02). 
cada instrumento nos permite diferentes possibilidades de contatos para a sua execução e extração sonora. Mas a soma de todos os fatores (já aqui discutidos) que ajudam na construção do gesto poderá, em seus diferentes níveis de assimilação, incorporar um desenho gestual congénere para distintos instrumentos (mesmo que as articulações sejam diversas). A adoção da forma linear curvilínea ou circular sugere uma não interrupção do movimento sobre todo este trecho. Ao tocar a primeira nota, o percussionista deverá preparar o ataque seguinte sem "quebrar" o movimento do corpo em direção à próxima nota. Logo, se esse tempo é lento (ou longo) e o corpo move-se ininterruptamente, o movimento corporal será consequentemente lento e sofrerá alterações conforme o as figuras de tempo se modificam.

\section{b) Ininterrupção da frase: sensação de continuidade em frases com eventos sonoros discrepantes}

Em muitos casos o distanciamento tímbrico entre os instrumentos de percussão age como uma barreira para a realização de ligaduras de frases ou mesmo para a criação de um sentido de fluência ou ininterrupção do texto musical entre os eventos sonoros realizados. 0 ritmo escrito muitas vezes pode contribuir para isso, uma vez que notas longas escritas para instrumentos de pouca reverberação podem expor essas limitações e causar uma sensação de interrupção ou mesmo conclusão em trechos que deveriam, a partir de uma análise interpretativa, indicar uma ideia de continuidade. Phènix (1982) de
BERNARD-MÂCHE possui um trecho que ilustra essa situação, alternando os motivos entre vibrafone e peles, gerando uma frase composta por distintos sons. 0 compositor não indica qualquer ligadura de frase. No entanto, tratando-se de uma variação do tema desenvolvido pelo vibrafone, a ligação entre os motivos faz-se fundamental para gerar um dinamismo na frase que denuncie a relação entre esses trechos. (Ex.32).

A escrita do pedal do vibrafone nos ajuda a perceber a conexão sonora existente entre a alternância dos instrumentos. Mais uma vez, o corpo poderá auxiliar na percepção da frase. Familiarizar-se com a disposição dos instrumentos na montagem é fundamental para a construção desse gesto. Nos casos de estudo, a obra foi executada sob duas perspectivas distintas de montagem (Ex.33 e Ex.34) ${ }^{19}$.

Em Ex.33 os instrumentos de pele estão suspensos acima do nível das lâminas, dispostos na posição vertical sob um ângulo de $45^{\circ}$. Nessa montagem o percussionista deverá realizar um leve movimento para frente e para trás nas transações entre os membranofones e o vibrafone. Em Ex.34 as peles estão suspensas ao mesmo nível das lâminas do vibrafone, numa posição horizontal (perpendicular ao chão) e/ou ligeiramente inclinadas para o intérprete. Não podemos deixar de destacar que nessa montagem 0 movimento das pernas, tronco e cabeça do intérprete será mais necessário e exigido pela disposição dos instrumentos.
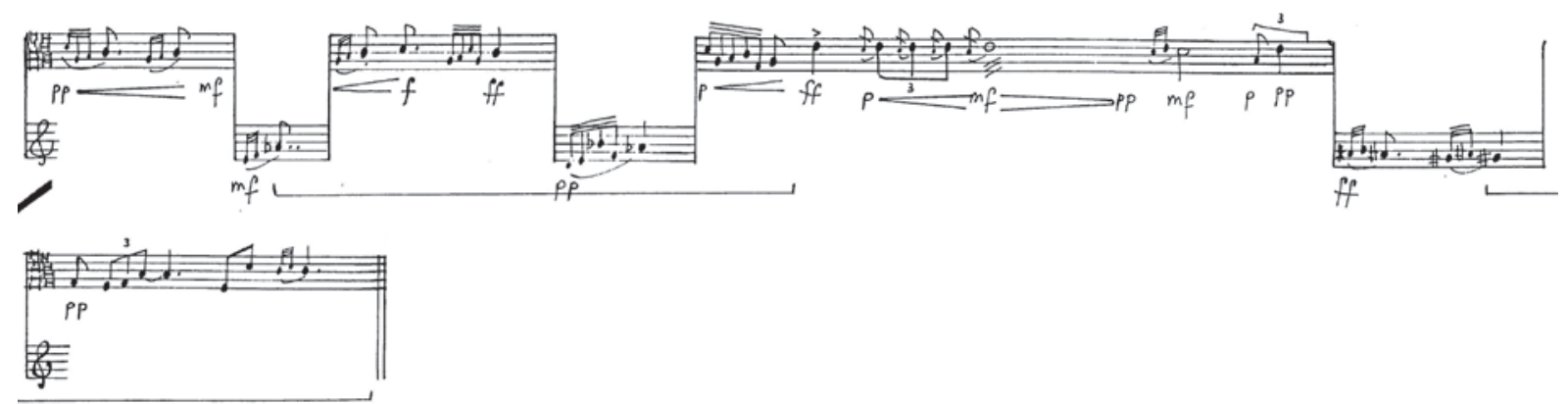

Ex.32: Phènix (1982) de BERNARD-MÂCHE: voz de cima: peles, voz de baixo: Vibrafone (2 sistema, p.02).

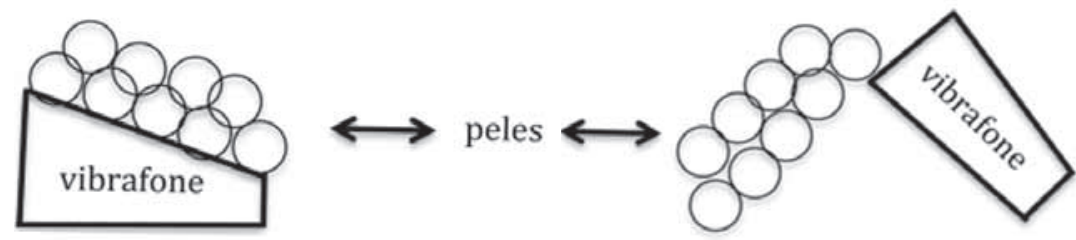


Para as duas montagens acreditamos que a interação gestual da forma linear curvilínea ou circular em congruência com os eventos sonoros permitirá um complemento à expressividade do intérprete na busca por essa sensação de homogeneidade que o trecho deve ter: " [...] é nas transições de uma posição para a outra que se verifica uma adequada mudança de expressão, o que determina a criação de um estilo de movimentos dinamicamente coerente" (LABAN, 1978 p.135). Em ambas as montagens deve-se buscar a relação curvilínea do corpo como um todo (inclusive cabeça, tronco e pernas). Ilustramos a seguir a relação gestual da forma linear curvilínea nesse trecho. 0 ritmo nesse trecho é mais vivo do que o ilustrado nos Ex.28 e Ex.29, por tanto o tempo de movimentação do corpo deverá também acompanhar esse carácter (Ex.35):

\section{c) Ilustração de distintas intenções do texto musical em eventos sonoros semelhantes:}

Phènix (1982) de BERNARD-MÂCHE ilustra nitidamente uma das questões que geralmente intriga o percussionista no momento de interpretar uma obra: o cruzamento de informações que seguem direções expressivas e musicais diferentes, mas que obtêm praticamente 0 mesmo resultado sonoro. Na p.05 o tema principal volta a ser exposto, com uma leve variação sobre o texto musical nas peles. Percebemos que o compositor sugere, através da indicação de pedal, que os sons obtidos pelos ataques realizados no vibrafone devem perdurar até a próxima intervenção nas peles (que possuem intervenções sonoras curtas seguidas de pausas). Duas questões aqui devem ser levadas em conta: o trecho isolado de cada instrumento e a soma das duas vozes no seu contexto sonoro e gestual. Nesse trecho ocorre uma controvérsia sonora nas peles, pois tocá-lo em dinâmica ff forçosamente criará uma relação com 0 Ex.29. Por não indicar regiões de toque distintas nas peles (ou baquetas e meios de contatos diferentes), o som extraído só não será o mesmo por serem realizados em alturas diferentes (Ex.36):

Interpretamos o pedal do vibrafone como um elo de ligação entre as duas linhas, onde o som e a mistura dos timbres devem conjugar o conteúdo musical proposto. 0 percussionista precisará encontrar uma atitude gestual que incite a percepção dos eventos sonoros descritos, estáticos e/ou curtos ritmicamente. A intenção de intervalo rítmico entre uma nota e outra deve ser conseguida através de outro mecanismo que não o sonoro. A forma linear resultante do gesto será preponderante para salientarmos a diferença entre os dois trechos.

Para a linha das peles sugerimos a aplicação da forma linear reta e/ou angular, onde o movimento corporal responsável pelos ataques agirá de forma pontual e não fluente. Para o vibrafone o gesto seguirá o caminho inverso, a forma

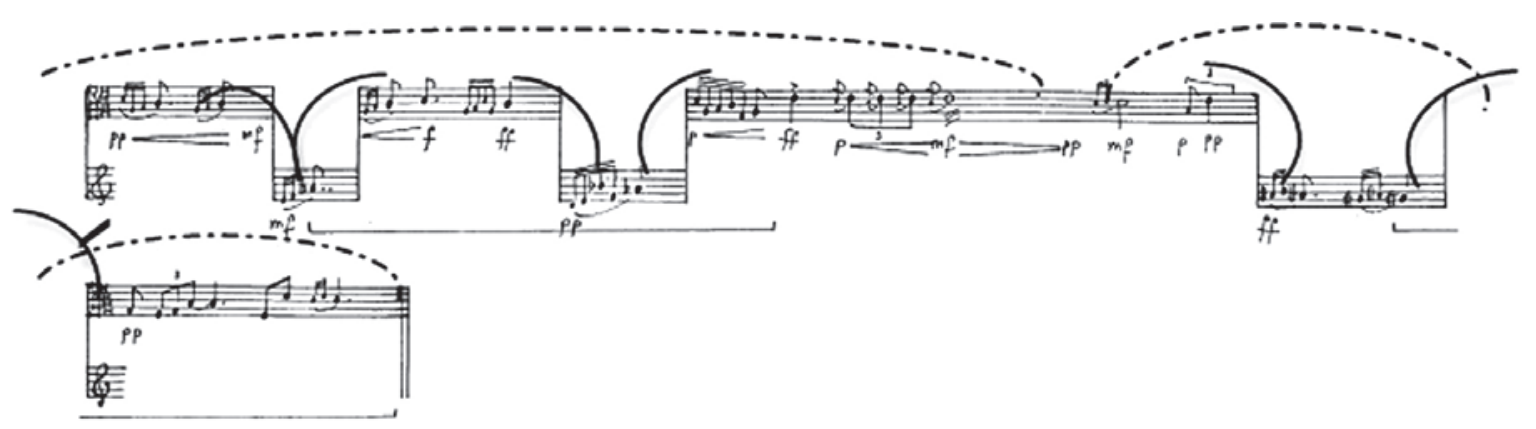

Ex.35: Phènix (1982) de BERNARD-MÂCHE: voz de cima: peles, voz de baixo: vibrafone (2 sistema, p.02).

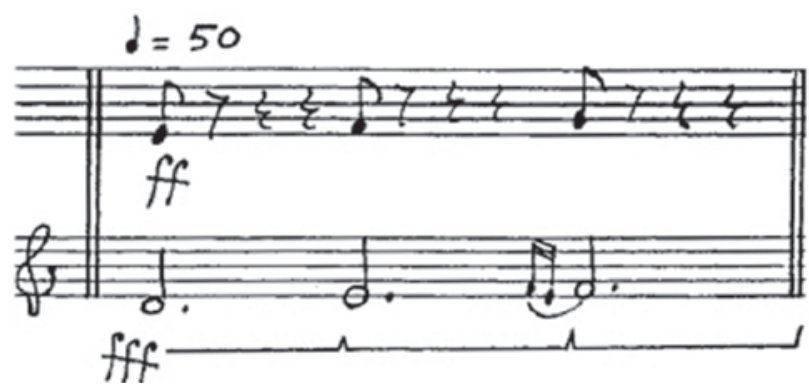

Ex.36: Phènix (1982) de BERNARD-MÂCHE: voz de cima: vibrafone, voz de baixo: Peles (2 sistema, p.05). 
linear circular ou curvilínea, estimulando a sensação de continuidade e ligação entre os ataques (Ex.37):

As relações rítmicas e de tempo do movimento devem ser diferentes em cada membro que executa seu respectivo instrumento, estando relacionadas diretamente com a sensação de fluência ou estaticismo representada pelo trecho escrito. A parte do corpo ocupada pela execução das peles agirá de forma mais rápida e objetiva. Por outro lado, o trecho do vibrafone seguirá o mesmo padrão de velocidade do movimento executado no outro excerto semelhante (Ex.30), já exemplificado. 0 objetivo aqui será o de provocar no espectador impressões onde predomine a sensação de mudança de caráter da exposição do tema representada temporalmente nas atitudes gestuais provocadas nas peles, uma vez que 0 trecho indicado para o vibrafone segue o mesmo critério desde o início da obra (em se tratando especificamente da exposição do tema principal).

\section{d) Visualização de intervenções sonoras pontuais:}

Utilizando como caso de estudo para esse tipo de aplicação da forma linear uma composição para grupo de música de câmara de percussão, ilustraremos a possibilidade de visualização de intervenções sonoras pontuais em trechos onde a massa de som é homogênea e ruidosa (enfatizando mais inarmônicos do que harmônicos), dificultando ou causando certa confusão acerca de, auditivamente, localizar essas intervenções em uma performance. A obra de Mário Laginha escrita para sete percussionistas intitulada Este pássaro não é preto (2002) possui um grande trecho escrito apenas para pratos tocados por todos os intérpretes (Ex.38).

Tratando-se os pratos de idiofones de altura não definida, a aglomeração de sons e indivíduos tocando ao mesmo tempo, onde a distância entre os intérpretes é quase nula (tocam lado a lado) acaba por dificultar a percepção das mensagens sonoras transmitidas

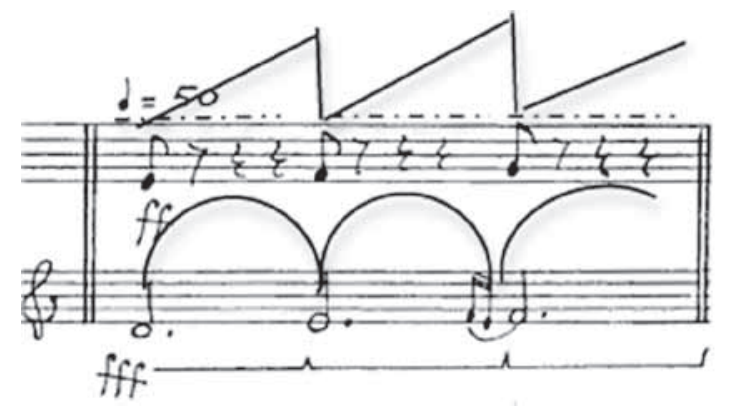

Ex.37: Phènix (1982) de BERNARD-MÂCHE: voz de cima: peles, voz de baixo: Vibrafone ( $2^{\circ}$ sistema, p.04).

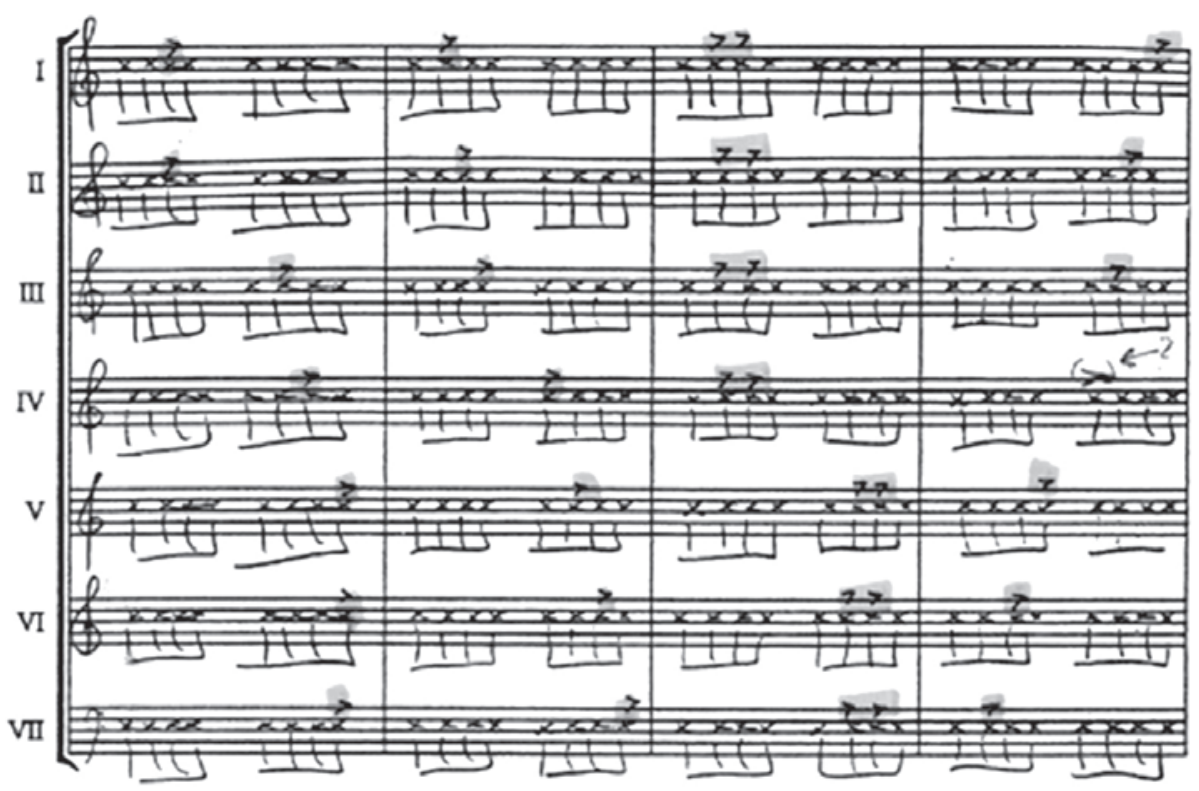

Ex.38: Este pássaro não é preto (2002) de LAGINHA: c.161-164. 
individualmente, sendo mais perceptível em termos auditivos o resultado do tutti. 0 ritmo constante, a prevalência de dinâmicas similares e a mesma técnica e exploração tímbrica utilizadas por todos os executantes causa à performance uma massa sonora uniforme particular. Por esse motivo o compositor procura, através da distribuição de acentos em momentos diferentes, dar "movimento" aos ataques em uníssono. A ideia é fazer com que pontos culminantes surjam, em diferentes momentos e intérpretes, por entre a massa sonora que se mantém estática ritmicamente (Ex.38).

0 problema a ser solucionado é fazer com que esses pontos culminantes sejam percebidos nitidamente pelo espectador. Mesmo os pratos estando abafados pelo contato com a superfície do chão e o trecho ser executado em dinâmica $p$, os ruídos provocados poderão confundir a divisão dos acentos em palco (Ex.39). Partindo do princípio de que o unissono torna trabalhosa (possivelmente confusa) a percepção de uma intervenção dinâmica individual, podemos correr o risco de perder a ideia que o trecho sugere. No c.162 percebe-se que poderá haver auditivamente uma certa dificuldade em determinar se o primeiro acento foi dado pelo perc. 1 ou perc. 2 já que na disposição em palco estão muito próximos um do outro, executando o mesmo ostinato rítmico. Esse problema ocorre entre todos os percussionistas, sendo perceptível nos C.c.163 e 164.

A forma linear poderá auxiliar na transmissão dessa ideia musical. Ao aproveitar o movimento dos braços para a execução de notas mais fortes, o intérprete será capaz de realçar o evento sonoro de destaque (acento) fazendo com que o membro responsável por esse ataque realize um gesto linear. A sua forma (reta ou circular) dependerá da interpretação coletiva uma vez que não há ligaduras de frase ou qualquer outra indicação de expressividade. A aplicação da forma linear deverá contribuir para que os pontos culminantes sejam mais facilmente identificáveis.

Existem outras possibilidades de o gesto contribuir para a percepção desses eventos sonoros pontuais sem a utilização da forma linear. Caso a interpretação do trecho convencione que os movimentos dos braços não devem ser excessivos em momento algum, a cabeça ou o tronco poderão salientar através de um rápido movimento (a direção não é preponderante) a execução dos acentos. Acreditamos que, ao utilizarmos o corpo na sua totalidade na performance percussiva, devemos abdicar de uma suposta hierarquia que possa transparecer dos membros superiores e cabeça em relação às outras partes, dando importância para a construção de todo o movimento corporal, uma vez que: "Even when there is only one tiny part of the body moving, the rest of the body serves as background for that part and so is active in a visual and choreographic way" (BLOM e CHAPLIN,1989 p.16). Essa perspectiva será preponderante para as situações gestuais aplicadas num sentido de performance musical, particularmente destinadas ao repertório que envolvem o emprego do GPE. Normalmente o movimento da cabeça é quase inerente à aplicação do acento, pois quanto mais energia concentrada e projetada pelo corpo para uma ação qualquer, maior será a reação natural da cabeça referente a isso. Reforçar de forma consciente essa relação da cabeça com o acento poderá ser outra saída gestual para o trecho em questão (Ex.38). A movimentação do tronco e joelhos (mesmo que de forma sutil) também poderá ser considerada para reforçar o súbito momento de discrepância dinâmica individual.

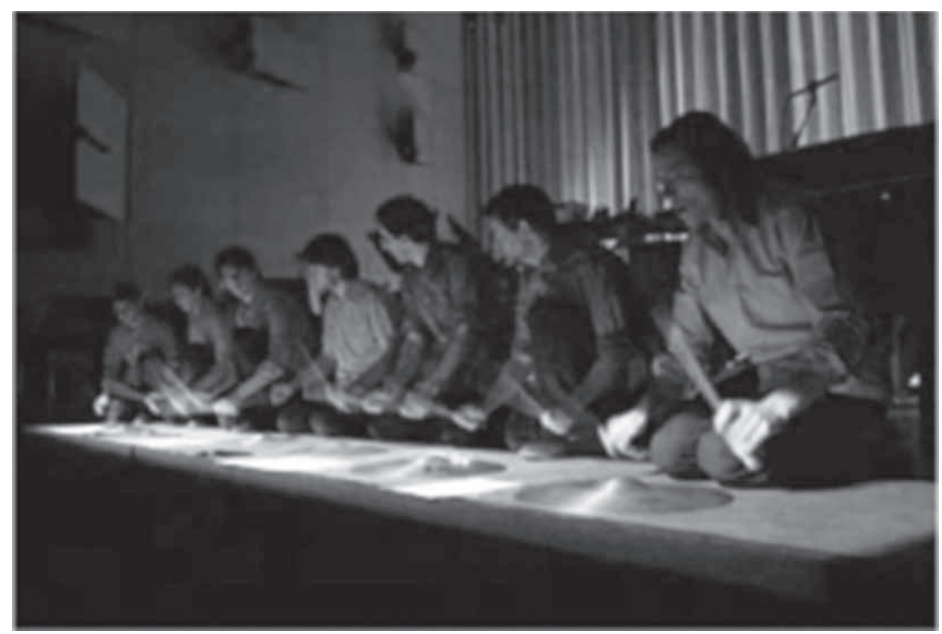

Ex.39: Este pássaro não é preto (2002) de LAGINHA: performance do Drumming G.P. 


\section{e) Visualização de relações antagônicas entre gesto e texto musical:}

0 compositor francês George Aperghis já em 1981 aplicava, mesmo que de forma indireta, a ideia de soundaccompanying gestures. Em sua obra Les Guetteurs des Sons (1981), observamos a requisição de movimentos com os braços que entram em concordância com as ressonâncias extraídas do instrumento (Ex.40).

A observação que faremos baseia-se no texto de apresentação de Gaston Sylvestre, presente na partitura, dividindo a obra em três partes. Nessa discussão nos interessa a primeira parte onde os percussionistas interpretam um bebê, recém nascido, que está descobrindo o universo do tato e do som (ou da influência do seu gesto sobre o som): "Au départ il faut imaginer les trois interprètes comme des 'nouveaux nées', comme des bébés qui découvert leurs mains [...]" (SYLVESTRE in APERGHIS, 1981). No c.24 o compositor pede apenas a movimentação do braço para baixo e para cima, sem tocar o instrumento, obedecendo o ritmo escrito, tratando-se apenas de uma intervenção gestual corporal. Percebe-se aqui que o compositor induz no espectador a ideia de que haverá uma intervenção sonora através do gesto realizado, o que não ocorre de fato. Já no c.25 a nota é tocada com uma deslocação do braço de forma lenta com um sentido vetorial vertical para cima (c.26). Note-se que esse movimento acompanhará o som resultante da nota tocada (tratando-se o instrumento de um tambor grave, o mesmo possui um tempo de decaimento do som suficiente para estabelecer essa relação com o movimento).
Nesse exemplo o movimento do braço não estará em concordância com o valor rítmico da nota tocada, mas com o som propagado no espaço onde o mesmo é produzido. Evidencia-se uma maior preocupação cênica com o trecho, uma vez que a velocidade do gesto realizado com o corpo (longo e constante) não condiz com o a parte escrita (curta e interrompida). Então, no fim do c.26, quando não há mais som, o percussionista volta a efetuar movimentos sem tocar o instrumento, podendo induzir novamente o espectador a imaginar eventos sonoros inexistentes. Outrossim, no c.27, o movimento do braço direito volta a ser duradouro, mas sem a produção do som. Aqui, começa-se a perceber que apenas o gesto, sem contato com o instrumento, não basta para a extração sonora.

Aperghis também explora uma ideia antinatural dos movimentos em relação às dinâmicas aplicadas. A dinâmica obedece a três princípios de Newton denominados leis do movimento ${ }^{20}$. 0 primeiro princípio nos diz que todo corpo permanece em estado de repouso ou velocidade constante, a não ser que uma força que atue sobre ele obrigue-o a modificar o estado de sua ação. 0 segundo princípio afirma que quando a força resultante aplicada sobre um corpo for diferente de zero, ele adquire uma aceleração proporcional à força, com mesma direção e sentido. 0 terceiro diz respeito a ação e reação. Ou seja, um corpo exercerá força contrária proporcional à qual foi sujeito por outro. A resultante da intensidade de dinâmica será proporcional à força-peso aplicada sobre o corpo.

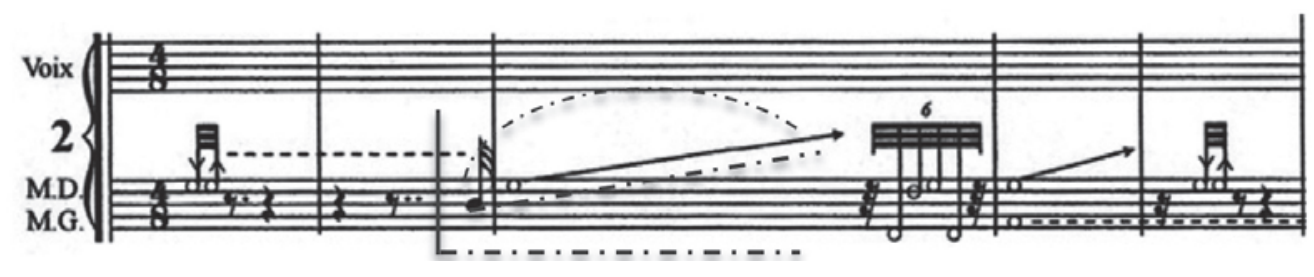

Ex.40: Les Guetteurs de Sons (1981) de APERGHIS: Percussionista 2. c.24-28.

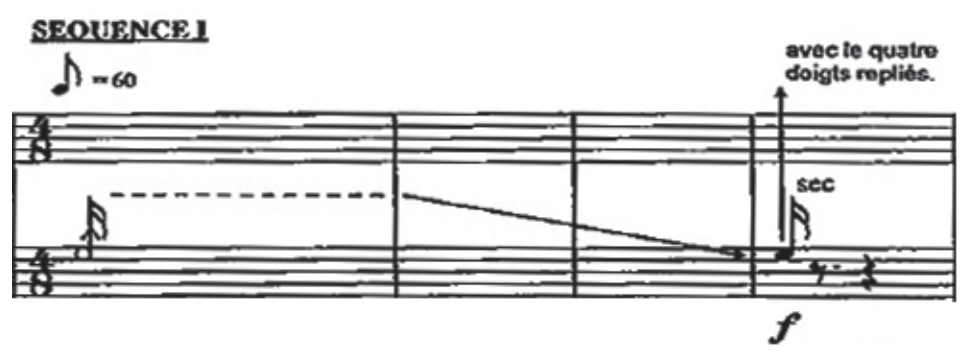

Ex.41: Les Guetteurs des Sons (1981) de APERGHIS: Percussionista 1. c.3-6. 
Contrariando as sensações quotidianas da relação da intensidade de dinâmica com o embate dos corpos envolvidos, o intérprete percussionista poderá criar mecanismos para subverter essa ideia intuitiva de força em relação à intensidade sonora. Observando Les Guetteurs des Sons (1981) de APERGHIS, percebemos que o compositor vai contra a ideia de correspondência direta entre o movimento corporal e os valores rítmicos das notas, bem como a intensidade sonora extraída em detrimento do gesto em si. Isso nos permite hipóteses sobre as mais variadas percepções e induções sobre 0 conteúdo musical. 0 rompimento de convenções entre 0 gesto e a resultante sonora ajuda-nos a perceber como o movimento corporal pode alterar o curso da interpretação de uma passagem musical, através de uma "contra indução" intuitiva do espectador (Ex.41).

Em Ex.41 podemos visualizar uma contradição entre o movimento realizado pelo percussionista (para baixo com o braço direito) a partir de c.4 e o som obtido em c.6. A movimentação corporal será lenta, porém o som obtido será em dinâmica $f$. 0 espectador, num primeiro momento intuitivo, fará uma conexão do movimento lento do braço a um toque sem grandes dimensões de dinâmica. No entanto esse trecho alterará, a partir de uma ótica sensorial natural, a sua percepção de forma súbita. Igualmente o intérprete deverá criar mecanismos que permitam a execução da dinâmica escrita, sem "quebrar" o sentido de continuidade (velocidade constante) do braço de c.4 a c.6. Nesse ponto o trabalho de tensão e relaxamento e a força muscular (LABAN 1978) deverão ser considerados, afim de estabelecer os pontos ideias dos movimentos exercidos pelo braço, pulso e mão para a execução desse trecho antagônico.

Através das leituras que realizamos sobre algumas possibilidades interpretativas e expressivas, condicionadas ao movimento corporal, chegamos a um consenso relativo ao que será o GPE em termos conceituais. Percebemos como esse gesto poderá atuar em convergência com o texto musical ou de forma contrária à ideia que une frequentemente som e movimento. Isso nos permite dizer que o emprego desse conceito não será regrado ou composto por uma aplicação estreita de movimentos. Tão pouco as saídas aqui encontradas para o desenvolvimento de uma expressão corporal condicionada às obras analisadas são únicas. Contudo, desenvolver o GPE nos auxiliou a compreender a possibilidade de transmissão (numa perspectiva audiovisual) do conteúdo musical das obras para percussão, executando-as de forma mais coerente relativamente às indicações previstas na partitura. Para nós o Gesto Percussivo Expressivo poderá sintetizar-se como:

\section{Ações corporais realizadas pelo percussionista que procuram induzir a \\ percepção de um evento sonoro em referência a um discurso musical apresentado.}

\section{Conclusão}

Através dos conceitos aqui discutidos procuramos oferecer condições ao percussionista para a construção de uma performance musical preocupada em gerir as relações gestuais do ponto de vista técnico, interpretativo e expressivo em detrimento de uma obra executada. 0 objetivo foi criar alternativas performativas que possam auxiliar o intérprete numa transmissão do conteúdo musical executado, tendo em vista a complexa relação que se estabelece geralmente entre os instrumentos de percussão, suas capacidades sonoras e os textos musicais presentes na partitura. Através disso admitimos que 0 desenvolvimento de futuros trabalhos que componham metodologias relacionadas com este campo de pesquisa possam efetivamente originar experimentos com a intenção de demonstrar analiticamente os níveis de influência gerados pelas relações gestuais em palco e de que maneira as mesmas atuam sobre a percepção do espectador em relação aos conteúdos musicais existentes nas obras executadas.

Observando os trabalhos realizados por SCHUTZ e LIPSCOMB (2004 e 2007), DAHL (2005) e BOUNEARD, WANDERLEY e GIBET (2011) acreditamos ter oferecido material performativo suficiente para a composição de um próximo passo de pesquisa que poderá passar pela construção de uma maquete experimental que venha utilizar processos que envolvam interfaces multimédia (vídeo, áudio e áudio/vídeo) e interajam com participantes, servindo como instrumento de recolha de dados para futuras análises a respeito da influência que o gesto poderá exercer sobre o espectador numa performance destinada à música para percussão. 


\section{Referências}

ANTUNES-PENA, L. (2011). Três Quadros sobre Pedra. Tübingen: Sumtone.

APERGHIS, G. (1981). Les Guetteurs de Sons. Paris: Editions Salabert.

BAILLEY, B. (1963). Mental and Manual Calisthenics for the Mallet Player. $1^{\circ}$ ed. New York: Warner Bros.

BARTÓK, B. (1939) Sonata para dois pianos e percussão. (ed. de 1942) Londres: Wakes \& Son.

BERNARD-MÂCHE, F. (1982). Phènix. Paris: Editions Durand.

BLOM, L. A., e L. T. CHAPLIN. (1989). The Intimate Act of Choreography. $1^{\text {a }}$ ed. Londres: Dance Books Ltd.

BOLÃO, O. (2003). Batuque é um Privilégio 3a ed. Rio de Janeiro: Lumiar.

CAGE, J. (2007). Silencio. Tradução: M. Pedraza. Madrid: Ediciones Àrdora.

(1939). First Construction (in Metal). New York: Edition Peters.

CAMURRI, A., e T. MOESLUND. (2010). Visual Gesture Recognition. In Musical Gestures - Sound, Movement, and Meaning. Editado por R. GODØY e M. LEMMAN. London: Routledge.

CATALÃO, J. (2008). Le Jeu organique du musicien: Des chemins pour une interprétation vivante en musique. PhD Thesis, Faculté de Musique Université de Montréal, Montréal.

CAZARIM, T. (2008). "Ação, pensamento, gesto, expressividade e a prática musical". Anais do SIMCAM 4 - IV Simpósio de Cognição e Artes Musicais. .

CHAIB, F. (2007). Exploração Tímbrica no Vibrafone: Análise Interpretativa da Obra Cálculo Secreto, de José Manuel López López. Dissertação de Mestrado, DeCA-Universidade de Aveiro, Aveiro.

DEANE, C (1983). Mourning Dove Sonet. EUA: Edição do autor.

FAZENDA, M. J. (1996). "Corpo Naturalizado: Experiência e discurso sobre duas formas de dança teatral americanas". In Corpo Presente, treze reflexões antropológicas sobre o corpo. Oeiras: Celta Editora.

Delalande, F. (1988). La gestique de Gould. In G. Guertin (Ed.), Glenn Gould: Pluriel, (p.85-111). Montréal: Courteau.

GIL, J. (2001). Movimento Total: O Corpo e a Dança. Lisboa: Relógio D'Água. (1980). Metamorfoses do Corpo. Tradução: M. C. Meneses. Lisboa: A Regra do Jogo, Edições Ltda.

GODØY, R., e M. LEMAN. (2010). Musical Gestures - Sound, Movement, and Meaning. 1 ${ }^{\text {a }}$ ed. New York: Routledge.

GRISEY, G (1976). Partiels pour 18 musicians. Milão: Ricordi.

JENSENIUS, A., M. WANDERLEY, R. GODØY, e MARC LEMAN. 2010. Concepts and Methods in Research. In Musical Gestures - Sound, Movement, and Meaning. Editado por R. GODØY e M. LEMAN. New York: Routledge.

LABAN, R. (1978). Domínio do Movimento. Tradução: A. M. B. DE VECHI e M. S. M. NETTO. 5a ed. São Paulo: Summus Editorial. 1a ed. McDonald \&t Evans Limited 1971.

LANG, D. (1991). The Anvil Chorus. Red Poppy.

LANGER, S. 1953. Sentimento e Forma. São Paulo: Perspectiva.

MCNEILL, D. (2005). Gesture and Though. Chicago: University of Chicago Press.

NOBRE, M. (1963).Variações Rítmicas.

OLIVEIRA, J.P. (1993). Kity. Portugal: Edição do autor.

OLIVEIRA, L. (2010). Radio Bossa. Porto: Edição do autor.

PIKE, K.L. (1967). Language in Relation to a unified theory of the Structure of Human Behavior. The Hague: Mouton.

PIRES, (1971). Ostinati. (ed. de 1982).Frankfurt: Zimmerman.

ROSAURO, N. (1992) .Rhapsody for Percussion Solo and Orchestra. Santa Maria: Pro-Percussão.

SCHICK, S. (2006). The Percussionist's Art: same bed, different dreams. Vol. 1. Rochester: University of Rochester Press. SEJOURNÉ, E. (1999). Concerto pour Vibraphone et Orchestre à Cordes. Paris: Alfonce Produtions.

STASI, C. (1990). Canção Simples de Tambor. São Paulo: Edição do autor.

TINOCO, L. (2003). Imaginary Dancescape a Melodrumming after Cocteau. Porto: Edição do autor.

TRALDI, C., J. MANZOLLI, e C. CAMPOS. (2009). "Os gestos Incidentais e Cênicos na Interpretação entre Percussão e Recursos Visuais". Ensaio Magazine, Outubro 2009, 16 - 18.

ZAMPRONHA, E. (2000/2006). Recycling Collaging Sampling. São Paulo: Edição do autor.

ZBIKOWSKI, L. M. (2011). Musical Gesture and Musical Grammar: A Cognitive Approach. In New Perspectives on Music and Gesture. Editado por A. GRITTEN e E. KING. Farnham: ASHGATE.

\section{Literatura Recomendada:}

BOUENARD, A., M. WANDERLEY, e S. GIBET. (2011). Analysis of Timpani Preparatory Gesture Paramterization. McGill University. 2009 [acessado em 26/10 2011]. Disponivel em http://hal.archives-ouvertes.fr/hal-00369241/en/. BOUSSAIC, P. (1973). La mesure des gestes, prolégomènes à la sémiotique gestuelle. Paris: The Hague. 
DAHL, S. (2005). On the beat: Human movement and timing in the production and perception of music. PhD Thesis, KTH Computer Science and Communication, KTH School of Computer Science and Communication, Stockholm.

DAHL, S., e A. FRIBERG. (2005). "Visual perception of expressives in musicians' body movements". Stokolm, 2005.

GRITTEN, A., e E. KING. 2010. Music and Gesture. 3a ed. Farnham: Ashgate.

GRITTEN, A., e E. KING. 2011. New Perspectives on Music and Gesture. Farnham: Ashgate.

HAKMRAST, T., K. GUETTLER, R. BADER, e R. GODØY. (2010). Gesture and Timbre. In Musical Gestures - Sound, Movement, and Meaning. Editado por R. GODØY e M. LEMAN. London: Routledge.

LEPPERT, R. 1993. The Sight of Sound - Music, Representation and the History of the Body. California: University of California Press.

SCHUTZ, M., e S. LIPSCOMB. (2007). "Hearing gestures, seing music : Vision influences perceived tone duration". Perception $36: 888-897$.

Evanston, II.

TINDALE, A., A. KAPUR, G. TZANETAKIS, P. DRIESSEN, e A. SCHLOSS. 2005. A Comparison of Sensor Strategies for Capturing Percussive Gestures. Vancouver, 2005.

TINDALE, A., A. KAPUR, G. TZANETAKIS, e I. FUJINAGA. Retrieval of percussion gestures using timbre classification techniques. Universitat Pompeu Fabra.

WANDERLEY, M, BRADLEY, V, MIDDLETON, N. MCKAY, C. e HATCH. W. (2005). The Musical Significance of Clarinetists' Ancillary Gestures: An Exploration of the Field. Journal of New Music Research 34:97 - 113.

\section{Notas}

1 Parte do Capítulo 03 da Tese de Doutorado de Fernando Chaib, intitulada: "O gesto na performance em percussão: uma abordagem sensorial e performativa". DeCA - Universidade de Aveiro.

2 Ver Referências.

3 Ver Literatura Recomendada.

4 Considerando instrumentos com pelo menos 3 oitavas como vibrafones, xilofones e marimbas.

5 Aqui, altura está no sentido de medida métrica e não numa conotação musical.

6 Chamaremos memória espacial a relação do espaço entre o instrumento e o intérprete.

7 Parte do "Poder Humano" como designou LABAN (1978, p.186).

8 Ver tópico 5.1, ponto b).

9 Ver tópico 4.3 Exemplos no repertório.

10 Obra para percussão múltipla e sons eletroacústicos.

11 Conversas on-line via Skype, uma vez que o compositor reside na Alemanha.

12 Pedra denominada "vidraçada".

13 Performance realizada em concerto no DeCA - Universidade de Aveiro (Portugal), a 28/07/2011.

14 Performance realizada em concerto a 17/11/2010, no VI Festival Internacional de Outono de Aveiro (Portugal).

15 Estas formas lineares são definidas como o "caminho" do movimento. LABAN (1978, p,72).

16 Obra de execução solo composta para vibrafone e nove instrumentos de pele.

17 Considerando nove instrumentos de pele com graduações de alturas diferentes, as dimensões não serão proporcionais o suficiente para possuírem o mesmo tempo de decaimento da nota do que, por exemplo, em um tímpano ou um bombo sinfónico. No estudo e performance realizados para este trabalho, foram escolhidos nove roto-toms entre 15' e 6' (medidas em polegadas).

18 Tendo em conta que o intérprete realiza-o em condições ideais à obra em questão (baquetas, dinâmicas, região do toque, articulação, etc.).

19 A montagem feita pelo autor (Ex.33) utilizou roto-toms em performance realizada no VI Festival Internacional de Outono 2010, (Aveiro, Portugal). A montagem da Ex.34 utilizou tom-tons em performance realizada no IMPULS'11 - 7th International Ensemble and Composers Academy for Contemporary Music (Graz, Áustria).

20 Isaac Newton (1642-1727) publicou as três leis do movimento bem como a lei universal da gravitação em seu tratado clássico Princpia Mathematica.

Fernando Chaib gradou-se em Bacharelado em Percussão pela UNESP, realizando Mestrado em Música/Performance na Universidade de Aveiro. Vem sendo galardoado com prêmios como solista e músico de câmara no Brasil, na Itália e em Portugal. É membro fundador do Grupo Durum Percussão Brasil e diretor e membro do Simantra Grupo de Percussão (Portugal). Possui Cds gravados com orquestras e grupos de música de câmara no Brasil, Europa e Ásia. Realiza concertos (a solo, como camerista, diante de orquestras e como músico convidado) nos continentes americano, asiático e europeu. No âmbito acadêmico possui artigos publicados em periódicos e anais de eventos científicos no Brasil e em Portugal. Está em fase de conclusão do seu Doutorado em Música na Universidade de Aveiro sob orientação do Prof. Dr. Evgueni Zoudilkine e Coorientação dos Prof. Dr. Carlos Stasi e Prof. Dr.Miquel Bernat, sendo bolsista da Fundação para a Ciência e Tecnologia (FCT) de Portugal e pesquisador do INET-MD. 